\title{
Response of Chickpea (Cicer aritienum L.) to Sulphur and Zinc Nutrients Application and Rhizobium Inoculation in North Western Ethiopia
}

Beza Shewangizaw ( $\sim$ bezashewangezaw@gmail.com )

Amhara Agricultural Research Institute, Debra Birhan agricultural research Center

Anteneh Argaw

School of Natural Resource Management and Environmental science, Haramaya University

Tesfaye Feyisa

Amhara Agricultural Research Institute

Endalkachew Wold-Meskel

World Agroforestry (ICRAF)

Birhan Abdulkadir

International livestock Research Institute

\section{Research Article}

Keywords: Rhizobium inoculation, growth parameter, nodulation, yield related trait, $\mathrm{P}$ uptake

Posted Date: December 9th, 2019

DOl: https://doi.org/10.21203/rs.2.18531/v1

License: (c) (i) This work is licensed under a Creative Commons Attribution 4.0 International License. Read Full License 


\section{Abstract}

In sub-Saharan Africa, multiple plant nutrients deficiency besides $\mathrm{N}$ and $\mathrm{P}$ is a major growth-limiting factor for crop production. As a result, some soils become non-responsive for Rhizobium inoculation besides $P$ application. Based on the soil test result, the soil of experimental sites had low OM, N, P, S and Zn. Hence, an experiment was carried out on-farm, during 2016/17 growing season, at Gondar Zuria woreda in Tsion and Denzaz Kebeles to evaluate the effect of Rhizobium inoculation, $\mathrm{S}$ and Zn application on yield, nodulation, $\mathrm{N}$ and $\mathrm{P}$ uptake of chickpea. The experiment included twelve treatments developed via factorial combination of two level of inoculation (Rhizobium inoculated, un-inoculated), three level of $S(0,15,30 \mathrm{~kg}$ Sulphur ha-1) and two levels of Zn (0,1.5 kg Zinc ha-1). The treatment was laid out in randomized complete block design with three replications. Results showed that the highest mean nodule number (15.3) and nodule volume (1.3 ml plant-1) over locations were obtained with Rhizobium inoculation integrated with $15 \mathrm{~kg} \mathrm{~S}$ and $1.5 \mathrm{~kg} \mathrm{Zn} \mathrm{ha-1}$ which resulted in $37.8 \%$ and $116.7 \%$ increment over the control check, respectively. It was also observed that combined application of Rhizobium and $30 \mathrm{~kg} \mathrm{~S}$ ha-1 caused the highest (6.7) mean nodulation rating and seed yield (1775.5 kg ha-1) over locations which resulted in $86.1 \%$ and $28 \%$ increase over the control check, respectively. Moreover, this treatment improved P use efficiency of chickpea. On the bases of observed result, it can be concluded that the response of chickpea to Rhizobium and $\mathrm{P}$ application can be improved by $\mathrm{S}$ application and Rhizobium inoculation with application of $30 \mathrm{~kg} \mathrm{~S}$ ha-1 with recommended rate of $\mathrm{P}$ and starter $\mathrm{N}$ is recommended for chickpea production at the experimental locations in Gonder Zuria Woreda.

\section{Introduction}

Nitrogen deficiency is a major factor limiting crop production in the tropics and subtropics (Wolde-meskel, 2007). To alleviate this limitation, the use of inorganic fertilizers by African farmers is limited as a result of high prices which is most of the time unaffordable by the subsistent farmers (Bagayoko et al., 2011). As a result, searching environmentally friendly and economically sound strategy is undeniably important (Lee and Song, 2007; Rigby and Cáceres, 2001). In this region, leguminous crops are extensively cultivated for human consumption. Moreover, this crops have the ability to reduce atmospheric N2 to usable form when it forms an association with root nodule inducing bacteria (Adjei et al., 2001). The occurrence of effective rhizobia in the soil is prerequisite for efficient legume-rhizobia symbiosis to deliver high $\mathrm{N}$ to the host plant and to enrich the soil $\mathrm{N}$ for the preceded crops (Choudhry, 2012). When the soil harbour ineffective in N2 fixation as well as insufficient number of rhizobia below 100 rhizobia g $^{-1}$ of soil, exogenous application of effective rhizobia is essential (Singleton and Tavares, 1986).

Chickpea (Cicer arietinum L.) is the second important pulse crops that belongs to the legume family. The crop is mainly produced for human consumption, animal feed and as a rotational crop with cereal. Chickpea is one of the health food that provide cheap but high quality protein especially for those developing countries that can't afford high price for animal protein. Moreover, it is a good source of carbohydrates, minerals and trace elements. On average dry chickpea kernels contains $56 \%$ fat, $47 \%$ starch, $23 \%$ protein, $6 \%$ soluble sugar, $6 \%$ crude fiber and $3 \%$ ash (Goa, 2014). Similarly, chickpea is an 
important crop in Ethiopia. In this country, chickpea productivity is the highest compared with the top ten producing countries of the world with contribution of about $2 \%$ of the total world chickpea production. It is also the largest producer of the crop in Africa accounting for about $46 \%$ of the production (Kassie et al., 2009). In Ethiopia, this crops shares $14 \%$ of the total area and $15 \%$ of the total production from major pulse crops.

For the last thirty years, several promising result has been obtained with inoculation under greenhouse as well as field condition in different plant species in Ethiopia (Beyene, 1988). Likewise, studies showed a positive influence of rhizobia inoculation in combination with NP fertilizer on chickpea. However, the productivity of chickpea after inoculation when compared with the productivity reported elsewhere as potential yield is very low. For example, the national average productivity of chickpea (1.89 tone ha) (CSA, 2014) was still lower than its potential yield (5.5 tone ha) (Belay, 2006) obtained on experimental stations. Such wide yield gap clearly indicates that research on chickpea should be focused on the development of appropriate technology for other constrain such as limited plant nutrient on top of developing improved varieties for higher yield and disease resistance.

An adequate supply of mineral nutrients to legumes enhances nitrogen $(\mathrm{N})$ fixation and yield (Ganetttmfshamurthy and Sammi Reddy, 2000). In the previous experiment in Gondar Zuria Woreda (Dinzaz, Degolla and Tsion Kebeles) revealed that there was a no a significant effect of P fertilizer application and Rhizobium inoculation on chickpea. Based on the soil test result we did, the soil of the study sites are deficient in $S$ and $Z n$ inaddition to $\mathrm{N}$ and $\mathrm{P}$ nutrients. But these nutrients are essential for both plant growth as well as the symbiosis between rhizobia and the host plant. Sulphur affects leguminous plant species growth since sulfur is important for nitrogenase (Mortenson and Thorneley, 1979) and ferredoxin (Yoch, 1979). Ferredoxin has a significant role in nitrogen dioxide and sulphate reduction, during assimilation of $\mathrm{N}$ by root nodule bacteria and free living $\mathrm{N}$-fixing soil bacteria (Scherer et al., 2008). Zinc is also involved in various host plant metabolic processes, nodule growth and N2 fixation process. Zn has also important role in activating plant enzymatic system, synthesis of chlorophyll and carbohydrates. Therefore, mitigating the $S$ and $Z n$ deficient in the soils of the study sites, we hypothesized that one way of improving the effective rhizobia in combination with $P$ thereby enhancing the productivity of chickpea. To attain this, it is essential to generate information by studying the response of chickpea to combined application of Rhizobium inoculation and S and Zn nutrient application.

\section{Materials And Methods}

\section{Study sites}

This on farm experiment was conducted in Gondar Zuria District, Tsion Siguaje and Denzaz Kebele.

\section{Tsion Siguaje kebele}


Tsion kebele is located at $1 \mathrm{~km}$ away from Woreda town Maksegnit. Agro-ecologically, it is categorized under Woynadega, with altitude range between 1800-2000 m.a.s.I. The total land area of the district is 1963.37 ha- $\mathrm{h}^{-1}$ and of which, agricultural land shares $1143 \mathrm{ha}^{-1}$. The dominant crops being cultivated in this district are sorghum, tef, chickpea, maize, mheat and, barley (GOZOARD, 2016). The dominant soil type covering $80 \%$ is Vertisols followed by $15 \%$ Nitisols and $5 \%$ Cambisols. Specifically, this on farm experiment was conducted at $37^{0} 33^{\prime} 33.9^{\prime \prime} \mathrm{E}-37^{0} 33^{\prime} 34.1^{\prime \prime} \mathrm{E}$ longitude and $12^{0} 25^{\prime} 00.9^{\prime \prime} \mathrm{N}-12^{0} 25^{\prime} 00.93^{\prime \prime} \mathrm{N}$ latitude with an elevation of $1924 \mathrm{~m}$.

\section{Denzaz Kebele}

This Kebele is located at $12 \mathrm{~km}$ away from woreda town Maksegint. Agro-ecologically, it is categorized as Woyenadega. According to GOZOARD (2016) the dominant soil type covering $64 \%$ is Cambisols followed by $21 \%$ Nitisols and $14.5 \%$ Vertisols. From the total area of the Kebele, the share of agricultural land is $1486 \mathrm{ha}^{-1}$ (43.7 \%). Tef, wheat, sorghum, chickpea, barley, and potato are the major crops cultivated in this kebele. Specifically, this on farm experiment was conducted at $37^{0} 36^{\prime} 24.9^{\prime \prime} \mathrm{E}-37^{0} 36^{\prime} 25.01^{\prime \prime} \mathrm{E}$ longitude and $12^{0} 25^{\prime} 08.1^{\prime \prime} \mathrm{N}-12^{0} 25^{\prime} 08.13^{\prime \prime} \mathrm{N}$ latitude with an elevation of $2037 \mathrm{~m}$.

The growth period extends from September to January. The total amount of rainfall during the growth period was $142.6 \mathrm{~mm}$, which is sufficient for the crop growth (fig.1A). The mean maximum and mean minimum temperature recorded were 27.7 and $12.2^{\circ} \mathrm{C}$, respectively. The maximum and minimum temperature recorded during the growth period were 30.1 and $7.6^{\circ} \mathrm{C}$, respectively (fig. 2B).

\section{Soil and Plant Sample Collection and Processing}

To identify the possible yield limiting essential plant nutrient in the study sites and hence to set up the treatment, soil samples were collected from those experimental sites on which diagnosis and demonstration of $\mathrm{P}$ fertilizer and Rhizobium inoculation trial were implemented by N2 Africa project. Five separate composite surface soil samples (0-20 cm depth) were collected from Gondar Zuria woreda (Tsion, Denzaz and Degola kebele) from 10 sampling spot of the entire experimental site before planting for determination of the physico-chemical properties of the soil and hence for identification of the limited plant nutrients. Soils were air dried, ground and mixed thoroughly and passed through a standard sieve. The samples were then analyzed for texure, $\mathrm{pH}, \mathrm{TN}, \mathrm{OC}, \mathrm{CEC}$, exchangeable cations ( $\mathrm{Ca}, \mathrm{Mg}, \mathrm{K}$, and $\mathrm{Na}$ ) extractable $\mathrm{P}$, extractable $\mathrm{S}$, and micronutrients ( $\mathrm{Zn}, \mathrm{Fe}, \mathrm{Cu}$ and $\mathrm{Mn}$ ). The numbers of indigenous rhizobia nodulating chickpea (Cicer artenium L.) present in the soils of the study sites that could nodulate chickpea was estimated by the most-probable-number (MPN), plant infection technique (Somasegaran and Hoben, 1994).

At physiological maturity, five randomly selected plants were harvested at the ground level and partitioned in to grain and haulm (straw). The plant material was dried to a constant weight in a forceddraft oven at $70^{\circ} \mathrm{C}$ to a constant weight, grounded and passed through $1 \mathrm{~mm}$ sieve for determination of $\mathrm{N}$ and $\mathrm{P}$ concentration in grain and haulm. 


\section{Experimental set-up}

The experiment comprised of three factors with two levels of Rhizobium inoculation $(+\mathrm{I}=$ Rhizobium inoculated and $-\mathrm{I}=$ Un-inoculated), three levels of sulphur (0,15 and $30 \mathrm{~kg} \mathrm{~S}$ ha) and two levels of $\mathrm{Zn}(0$ and $1.5 \mathrm{~kg} \mathrm{Zn} \mathrm{ha).} \mathrm{The} \mathrm{factorial} \mathrm{combinations} \mathrm{of} \mathrm{the} \mathrm{three} \mathrm{factors} \mathrm{were} \mathrm{laid} \mathrm{in} \mathrm{RCB} \mathrm{design} \mathrm{with} \mathrm{three}$ replications.

\section{Treatment combinations}

1. Control check

2. Rhizobium inoculation alone $(+1)$

$3.1 .5 \mathrm{~kg}$ ha Zinc alone $(-\mid * 1.5 \mathrm{Zn})$

4. $15 \mathrm{~kg}$ ha Sulphur alone (-I*15S)

$5.30 \mathrm{~kg}$ ha Sulphur alone $(-1 \star 30 \mathrm{~S})$

6. Rhizobium inoculation $+15 \mathrm{~kg}$ ha Sulphur $\left(+{ }^{\star} 15 \mathrm{~S}\right)$

7. Rhizobium inoculation $+30 \mathrm{~kg}$ ha Sulphur $(+\mid * 30 \mathrm{~S})$

8. Rhizobium inoculation $+1.5 \mathrm{~kg}$ ha Zinc $(+1 * 1.5 \mathrm{Zn})$

9. $15 \mathrm{~kg}$ ha Sulphur $+1.5 \mathrm{~kg}$ ha Zinc $\left(-1 * 15 \mathrm{~S}^{*} 1.5 \mathrm{Zn}\right)$

10. $30 \mathrm{~kg}$ ha Sulphur $+1.5 \mathrm{~kg}$ ha Zinc $\left(-1 * 30 \mathrm{~S}^{*} 1.5 \mathrm{Zn}\right)$

11. Rhizobium inoculation $+15 \mathrm{~kg}$ ha Sulphur $+1.5 \mathrm{~kg}$ ha Zinc $\left(+\left.\right|^{\star} 15 S^{\star} 1.5 \mathrm{Zn}\right)$

12. Rhizobium inoculation $+30 \mathrm{~kg}$ ha Sulphur $+1.5 \mathrm{~kg}$ ha Zinc $\left(+{ }^{*} 30 \mathrm{~S} * 1.5 \mathrm{Zn}\right)$

Moreover, negative treatment without inorganic fertilizer (including starter $\mathrm{N}$ and $\mathrm{P}$ ) and Rhizobium inoculation was included as a satellite treatment for the determination of nutrient uptake and hence nutrient efficiency determination.

The experimental sites were prepared using standard cultivation practices before planting. Trial fields were plowed using oxen-drawn implements at the depth of about $10 \mathrm{~cm}$ for first plowing and $15 \mathrm{~cm}$ for the last pass. Sowing was done on September 13 and 15/2016 at Denzaz and Tsion, respectively. Improved chickpea varieties (Arerti) was selected based on the recommendation of research because of local adaptation and market preferences. This variety are relatively long duration (105-155 days) relative

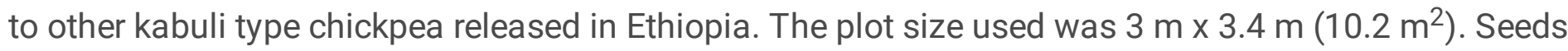
were sown in rows by maintaining $30 \mathrm{~cm}$ and $10 \mathrm{~cm}$ between the rows and plants, respectively. There were 10 rows per plant and 34 plants in each row. A net plot size was $3.4 \mathrm{~m} \times 1.8 \mathrm{~m}\left(6.12 \mathrm{~m}^{2}\right)$ was used for the final harvest. The spacing between each treatment and block were $1 \mathrm{~m}$ and $1.5 \mathrm{~m}$, respectively. Ridge was constructed between plot and plot to remove cross contamination of fertilizer and inoculant between plot and rigdge.

All treatments (except the negative control) received equal amount of starter inorganic $20 \mathrm{~kg} \mathrm{~N} \mathrm{ha}^{-1}$ (Argaw and Muleta, 2016), $20 \mathrm{~kg} \mathrm{P} \mathrm{ha}^{-1}$ (Ahlawat and Ali, 1993; Meen et al., 2010) in the form of Urea and 
Triple super phosphate, respectively. Sulfur and zinc fertilizer were applied in the form of calcium sulfate and zinc sulfate, respectively. Zinc sulfate was applied on foliar parts (Habbasha et al., 2013; Pathak et al., 2012). The remaining fertilizers were applied directly to the soil at the time of planting (Corp et al., 2004).

Chickpea Mesorhizobium strain CP-41 that was selected based on its ability to enhance nodulation and grain yield under wide ecological condition (Funga et al., 2016; Tena et al., 2016) was obtained from MBI (Menagesha Biotechnology Industry). Seed inoculation was performed before sowing using the procedure developed by Fatima et al. (2007). To ensure the sticking of the applied inoculant to the seeds, the required quantity of seed was suspended in 1:1 ratio in 10\% sugar solution. The inoculant was gently mixed with dry seeds at the rate of $10 \mathrm{~g}$ per $\mathrm{kg}$ of seed. Inoculation was done just before sowing under shade to maintain the viability of cells and allow to air dry for a few minutes and then the inoculated seeds were sown at recommended rate and spacing to the respective plots. To avoid cross contamination, plots with un-inoculated seeds were planted first followed by the inoculated ones.

Sampling for nodulation was performed by excavating the roots of plants randomly from two rows next to boarder rows of each plot at the mid flowering stage of the crop. The sampled plants from each plot were used to record the following observations; nodule number, nodule dry weight and effectiveness of nodule. Other agronomic and yield related data were also collected on different growth stage as well as at harvest and after harvesting of the test crop.

At the end of the season, the central six rows from each plot $(3.4 \mathrm{~m} \times 1.8 \mathrm{~m})$ was harvested at the ground level. Then, total biomass (the grain and haulm yield) was weighted at harvest. After threshing, seeds were cleaned and weighed. Seed moisture content was measured using a gravimetric method. Total biomass (on dry matter basis) and grain yields were adjusted to a moisture content of $12.5 \%$. Haulm yield was obtained by subtracting grain yield from total biomass yield.

Phosphorus and Nitrogen uptake by seed and haulm was determined from the $\mathrm{P}$ and $\mathrm{N}$ content of respective part after multiplying the seed yield and haulm yield, respectively. Phosphorus Use Efficiency were calculated with the help of the following formula

PUE $=\frac{\text { biological yield at higher } \mathrm{P}-\text { biological yield at lower } \mathrm{P}}{\mathrm{P} \text { uptake in biomas at higher } \mathrm{P}-\mathrm{P} \text { uptake in biomas at lower } \mathrm{P}}$ (Fageria and Santos, 2002)

Where PUE $=$ Phosphorus use efficiency

\section{Statistical analysis}

The collected data were subjected to analyses of variance (ANOVA) to evaluate the treatment effect on the selected parameters using SAS 9.1 statistical software. Where ever the treatment effect were significant, mean separation were made using the least significance (LSD) test at $5 \%$ level of probability (Gomez and Gomez, 1984). 


\section{Results And Discussion}

\section{Soil property}

Soil texture is one of the inherent soil properties less affected by management and which determines nutrient status, organic matter content, air circulation and water holding capacity of a given soil. Based on the soil analysis made, the soil texture of the entire sites was clay. This soil is characterized by high water holding capacity. Due to this, farmers of the study area plant chickpea on residual soil moisture starting from the first to last week of September. The soil pH of trial sites was ranged between 7.0 to 7.9 with a mean value of 7.4, which is neutral and ideal for the production of most field crops including chickpea. Based on the results obtained for soil analysis, the average total nitrogen $(\mathrm{N})$, available phosphorus (P), available Sulfur (S) were found to be below the critical levels (Table 1); and not optimal for crop production. These values were $0.052 \%, 7.42 \mathrm{ppm}$ and $7.5 \mathrm{ppm}$, respectively, for N, P and $\mathrm{S}$. Thus, based on the rating developed by (Tekalign, 1991) for Ethiopian soil, the average total nitrogen content of the soil was low (Table 1). This result is in line with the previous findings of many scholars who reported that $\mathrm{N}$ is one of the most deficient elements in the tropics for crop production (Hailu et al., 2015; Mengel and Kirkby, 1987; Mesfin, 1998). Similarly, based on the soil rating developed by Landon (1991), the available $P$ was rated as low. Moreover, according to Lewis (1999) S content of all study sites ranged from very low-to-low (Table1). The low $S$ was also expected because the experimental soil had low organic matter content (source of about $95 \%$ of S) indicating that it's potential to supply $S$ to plant growth through mineralization is low. Other authors also reported deficiency in S in Vertisols of Ethiopia (EthioSIS, 2016; Fanuel, 2015; Habtamu et al., 2014; Hailu et al., 2015; Lelago et al., 2016).

The exchangeable cations $(\mathrm{EC}=0.1 \mathrm{dS} / \mathrm{m})$ and cation exchange capacity $\left(\mathrm{CEC}=58.7 \mathrm{cmo}(+) \mathrm{kg}^{-1} \mathrm{soil}\right)$ of the soil were also determined (Table 1). The average contents of potassium (K), calcium (Ca) and magnesium (Mg) in the soil were $0.8,47.5$ and $23 \mathrm{cmo}(+) \mathrm{kg}^{-1}$ soil, respectively (Table 1). Based on the rating developed for those nutrients it were found to be above the optimum range (Berhanu, 1985; Hazelton and Murphy, 2007). This result is also in agreement with former findings in different vertisols dominated areas of Ethiopia (Desta, 1982; Fassil and Charles, 2009; Hailu et al., 2015; Kamara et al., 1989; Lemma and Smit, 2008).

The average $\mathrm{Fe}, \mathrm{Cu}$ and $\mathrm{Mn}$ of the soil were found above the critical range, which are 12.9, 2.4 and 18.7 $\mathrm{mg} \mathrm{kg}^{-1}$ soil respectively. In contrast, $\mathrm{Zn}$ deficiency is widespread in many of the world's major chickpeagrowing areas (Cakmak et al., 1995). According to Ahlawat et al. (2007) chickpea is more sensitive to Zn deficiency. Accordingly, the DTPA extractable Zn content in the soil ranged from $0.4 \mathrm{mg} \mathrm{kg}^{-1}$ (site 5) to 0.6 $\mathrm{mg} \mathrm{kg}^{-1}$ (site 2) (Table 1). According to Lindsay and Norvell (1978), all sites had below the critical value of $1.0 \mathrm{mg} \mathrm{kg}^{-1}$. This could be due to the fact that $\mathrm{Zn}$ has a tendency of being adsorbed on clay sized particles (Alloway, 2008). Previous research also indicated that in neutral to alkaline soils where chickpea is usually grown, $\mathrm{Zn}$ deficiency can often be encountered (Roy et al., 2006). Other research findings also confirmed deficiency of Zn in Vertisols of Ethiopia (EthioSIS, 2016; Haileselassie et al., 2011; Yifru and Mesfin, 2013). 


\section{Native rhizobia population}

The MPN background rhizobia nodulating chickpea in Tsion and Denzaz site were varied between $17 \mathrm{x}$ 10-1 to low ( $<10 \times 10^{-1}$ rhizobia cells $\mathrm{g}^{-1}$ soil) though the districts have many years of experience in chickpea cultivation (IFPRI, 2015). Indicating that native rhizobia population is not abundant enough to initiate optimum nodulation and provide sufficient amount of N through BNF (Slattery et al., 2004).

\section{Nodule number}

Nodule number is one of the parameters in assessing the performance of nodules in accordance with their ability to fix atmospheric nitrogen. In this regard; application of Rhizobium inoculation, $\mathrm{S}$ and $\mathrm{Zn}$ was found to be significant on nodule number (Table 2). At Tsion site, the highest nodule number (15.7) was obtained from the combined application of $15 \mathrm{~kg} \mathrm{~S}$ and $1.5 \mathrm{~kg} \mathrm{Zn} \mathrm{ha}^{-1}$ while the lowest (10.9) was obtained from Rhizobium inoculation and $1.5 \mathrm{~kg} \mathrm{Zn} \mathrm{ha}^{-1}$. At Denzaz site, the highest nodule number (15.8) was obtained from the combined application of Rhizobium inoculation, $15 \mathrm{~kg} \mathrm{~S}$ and $1.5 \mathrm{~kg} \mathrm{Zn} \mathrm{ha-1}$ whereas the lowest (9.3) was from the control check as well as $15 \mathrm{~kg} \mathrm{~S} \mathrm{ha}^{-1}$ alone. The highest (15.3) mean nodule number over locations was obtained from Rhizobium inoculation integrated with $15 \mathrm{~kg} \mathrm{~S}$ and $1.5 \mathrm{~kg} \mathrm{Zn} \mathrm{ha}^{-1}$ which resulted in $37.8 \%$ increment over the control check.

Table 1.

Physico-chemical properties of the soil before planting

\begin{tabular}{|c|c|c|c|c|c|c|}
\hline \multirow{3}{*}{ Parameters } & \multicolumn{6}{|c|}{ Before planting } \\
\hline & \multicolumn{5}{|c|}{ Sites } & \multirow[t]{2}{*}{ Mean } \\
\hline & $1 /$ Degola $^{+}$ & $2 /$ Degola $^{+}$ & 3/Tsion ${ }^{*}$ & $4 /$ Denzaz $^{+}$ & 5/Denzaz ${ }^{*}$ & \\
\hline Textural class $^{a}$ & Clay & Clay & Clay & Clay & Clay & \\
\hline $\mathrm{pH}\left(1: 2.5 \mathrm{H}_{2} \mathrm{O}\right)^{b}$ & 7.3 & 7.0 & 7.9 & 7.6 & 7.0 & 7.4 \\
\hline $\operatorname{Ec}(\mathrm{dS} / \mathrm{m})^{\mathrm{c}}$ & 0.09 & 0.07 & 0.13 & 0.09 & 0.09 & 0.1 \\
\hline Organic Carbon (\%) ${ }^{d}$ & 0.61 & 0.61 & 0.73 & 0.68 & 0.74 & 0.67 \\
\hline Total N (\%) e & 0.05 & 0.04 & 0.07 & 0.05 & 0.05 & 0.05 \\
\hline Available P $\left(\mathrm{mg} \mathrm{kg}^{-1}\right)^{\mathrm{f}}$ & 0.8 & 17.1 & 2.8 & 9.7 & 6.7 & 7.42 \\
\hline Available S $\left(\mathrm{mg} \mathrm{kg}^{-1}\right)^{\mathrm{g}}$ & 7.6 & 8.0 & 10.5 & 5.4 & 7.6 & 7.8 \\
\hline $\operatorname{CEC}\left(\mathrm{cmo}(+) \mathrm{kg}^{-1} \text { soil }\right)^{\mathrm{h}}$ & 62.6 & 57.6 & 60.1 & 60.1 & 53.1 & 58.7 \\
\hline $\mathrm{Na}^{+}\left(\mathrm{cmo}(+) \mathrm{kg}^{-1}\right.$ soil) ${ }^{\mathrm{i}}$ & 0.2 & 0.2 & 0.3 & 0.2 & 0.2 & 0.2 \\
\hline $\mathrm{K}^{+}\left(\mathrm{cmo}(+) \mathrm{kg}^{-1} \text { soil }\right)^{\mathrm{i}}$ & 0.6 & 1.1 & 0.8 & 0.9 & 0.8 & 0.8 \\
\hline $\mathrm{Ca}^{2+}\left(\mathrm{cmo}(+) \mathrm{kg}^{-1} \text { soil }\right)^{\mathrm{g}}$ & 51.7 & 41.4 & 56.7 & 48.6 & 39.2 & 47.5 \\
\hline $\mathrm{Mg}^{2+}\left(\mathrm{cmo}(+) \mathrm{kg}^{-1} \text { soil }\right)^{g}$ & 27.1 & 25.4 & 16.9 & 22.6 & 23.1 & 23.0 \\
\hline $\mathrm{Fe}\left(\mathrm{mg} \mathrm{kg}^{-1}\right.$ soil) ${ }^{\mathrm{k}}$ & 8.4 & 20.5 & 8.3 & 10.8 & 16.7 & 12.9 \\
\hline $\mathrm{Cu}\left(\mathrm{mg} \mathrm{kg}^{-1}\right.$ soil) ${ }^{\mathrm{k}}$ & 2.7 & 2.5 & 1.5 & 2.9 & 2.5 & 2.4 \\
\hline $\mathrm{Mn}\left(\mathrm{mg} \mathrm{kg}^{-1}\right.$ soil) ${ }^{\mathrm{k}}$ & 24.5 & 18.1 & 11.3 & 15.5 & 24.2 & 18.7 \\
\hline $\mathrm{Zn}\left(\mathrm{mg} \mathrm{kg}^{-1}\right.$ soil) ${ }^{\mathrm{k}}$ & 0.5 & 0.6 & 0.5 & 0.5 & 0.4 & 0.5 \\
\hline
\end{tabular}

Method: ${ }^{\text {a }}$ Hydrometer; ${ }^{\mathrm{b}}$ Potentiometric-water extract; ${ }^{\mathrm{c}}$ conductivity-water extract; ${ }^{\mathrm{d}}$ Walklay and Black; ${ }^{\mathrm{e}}$

Kjeldahl; ${ }^{\mathrm{f}}$ Olsen; ${ }^{\mathrm{g}}$ Turbidimetric; ${ }^{\mathrm{h}}$ Ammonium acetate; ${ }^{\mathrm{i}}$ Ammonium Acetate Extract-Flame photometry; ${ }^{\mathrm{g}}$ Ammonium Acetate Extract- EDTA Titration; ${ }^{\mathrm{k}}$ Diehylenetriaminepentaacetic acid (DTPA).

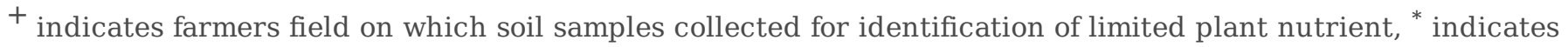
farmers field soil samples collected as well as on farm experiment conducted.

\section{Nodule dry weight}


In the case of nodule dry weight, the highest and lowest value at Tsion were obtained in response to Rhizobium inoculation when integrated with $30 \mathrm{~kg} \mathrm{~S} \mathrm{ha}^{-1}$ and $1.5 \mathrm{~kg} \mathrm{Zn} \mathrm{ha}^{-1}$ and Rhizobium inoculation alone, respectively (Table 2). At Denzaz, the highest (46.7 mg plant ${ }^{-1}$ ) and lowest (14.7 mg plant $\left.{ }^{-1}\right)$ nodule $^{2}$ dry weight were obtained from Rhizobium inoculation when integrated with $15 \mathrm{~kg} \mathrm{~S} \mathrm{ha}^{-1}$ and application of $1.5 \mathrm{~kg} \mathrm{Zn} \mathrm{ha}^{-1}$ alone, respectively. The highest (48.5 $\left.\mathrm{mg} \mathrm{plant}^{-1}\right)$ mean value of nodule dry weight combined over locations was found when Rhizobium inoculation was integrated with $15 \mathrm{~kg} S$ ha which resulted in $22.2 \%$ increase over the control check.

\section{Effectiveness of nodules}

The effectiveness of nodules in its ability to fix atmospheric nitrogen in response to inoculation, $\mathrm{S}$ and $\mathrm{Zn}$ was assessed using nodule color. Nodule color was found to ranged from pink to slightly dark red. The color observed in the inoculated and un-inoculated plots was comparable to each other indicating the non-effectiveness of inoculated rhizobia over the native rhizobia.

Table 2.

Number of nodule, nodule dry weight and Effectiveness of nodule as affected by Rhizobium, S and Zn rates

\begin{tabular}{|c|c|c|c|c|c|c|c|c|c|}
\hline \multirow[t]{2}{*}{ Treatment } & \multicolumn{3}{|l|}{ NNPP } & \multicolumn{3}{|c|}{ NDWPP (mg plant ${ }^{-1}$ ) } & \multicolumn{3}{|l|}{$\mathrm{EN}$} \\
\hline & Tsion & Denzaz & Mean & Tsion & Denzaz & Mean & Tsion & Denzaz & Mean \\
\hline Control check & $13^{\mathrm{de}}$ & $10.5^{\mathrm{cd}}$ & $11.1^{\mathrm{de}}$ & $52^{b}$ & $27.3^{\mathrm{bcd}}$ & $39.7^{\mathrm{C}}$ & $2.8^{\mathrm{a}}$ & $2.8^{\mathrm{ab}}$ & $2.8^{\mathrm{a}}$ \\
\hline$-\mathrm{I} * 1.5 \mathrm{Zn}$ & $15.6^{\mathrm{ab}}$ & $10.5^{\mathrm{bcd}}$ & $13.8^{\mathrm{b}}$ & $50.3^{\mathrm{bc}}$ & $14.7^{\mathrm{i}}$ & $32.5^{d}$ & $2.7^{\mathrm{ab}}$ & $2.7^{\mathrm{abc}}$ & $2.7^{\mathrm{abcd}}$ \\
\hline$-I * 15 S$ & $12.9^{\mathrm{def}}$ & $11.1^{\mathrm{bc}}$ & $11.2^{\text {cde }}$ & $47^{\mathrm{cd}}$ & $26.7^{\text {cde }}$ & $36.8^{\mathrm{C}}$ & $2.5^{\mathrm{bc}}$ & $2.4^{\mathrm{c}}$ & $2.5^{d}$ \\
\hline$-I^{*} 15 \mathrm{~S} * 1.5 \mathrm{Zn}$ & $15.7^{\mathrm{a}}$ & $11.9^{\mathrm{efg}}$ & $13.7^{\mathrm{b}}$ & $37.3^{\mathrm{e}}$ & $19.3^{g h}$ & $28.3^{f}$ & $2.7^{\mathrm{ab}}$ & $2.8^{\mathrm{ab}}$ & $2.8^{\mathrm{abc}}$ \\
\hline$-I * 30 S$ & $14^{\mathrm{bcd}}$ & $10.7^{\mathrm{bcd}}$ & $12.5^{\mathrm{bc}}$ & $39^{\mathrm{e}}$ & $22.7^{\mathrm{efg}}$ & $30.8^{\text {def }}$ & $2.6^{\mathrm{ab}}$ & $2.6^{\mathrm{abc}}$ & $2.6^{\mathrm{abcd}}$ \\
\hline -I*30S*1.5Zn & $12.4^{\text {defg }}$ & $11.9^{\mathrm{bc}}$ & $11.9^{\text {cde }}$ & $47.7^{\mathrm{bcd}}$ & $28^{\mathrm{bcd}}$ & $37.8^{\mathrm{c}}$ & $2.7^{\mathrm{ab}}$ & $2.9^{\mathrm{a}}$ & $2.8^{\mathrm{a}}$ \\
\hline$+\mathrm{I}$ & $13.4^{\mathrm{cde}}$ & $9.3^{\mathrm{d}}$ & $11.9^{\text {cde }}$ & $29.3^{f}$ & $16^{\text {hi }}$ & $22.7^{\mathrm{g}}$ & $2.6^{\mathrm{ab}}$ & $2.6^{\mathrm{abc}}$ & $2.6^{\mathrm{abcd}}$ \\
\hline$+I^{*} 1.5 \mathrm{Zn}$ & $10.9^{g}$ & $12.1^{\mathrm{b}}$ & $10.7^{\mathrm{e}}$ & $44^{\mathrm{d}}$ & $31.3^{b}$ & $37.7^{\mathrm{c}}$ & $2.6^{\mathrm{ab}}$ & $2.8^{\mathrm{ab}}$ & $2.7^{\mathrm{abc}}$ \\
\hline$+I^{*} 15 S$ & $11.3^{\mathrm{fg}}$ & $9.3^{d}$ & $11.2^{\mathrm{cde}}$ & $50.3^{\mathrm{bc}}$ & $46.7^{\mathrm{a}}$ & $48.5^{\mathrm{a}}$ & $2.7^{\mathrm{ab}}$ & $2.9^{\mathrm{ab}}$ & $2.8^{\mathrm{ab}}$ \\
\hline$+\mathrm{I} * 15 \mathrm{~S} * 1.5 \mathrm{Zn}$ & $14.7^{\mathrm{abc}}$ & $11.7^{\mathrm{bc}}$ & $15.3^{\mathrm{a}}$ & $36.3^{\mathrm{e}}$ & $22^{\text {eg }}$ & $29.2^{\mathrm{ef}}$ & $2.4^{\mathrm{C}}$ & $2.7^{\mathrm{abc}}$ & $2.5^{\mathrm{cd}}$ \\
\hline$+I^{*} 30 S$ & $14^{\mathrm{bcd}}$ & $11.1^{\mathrm{bc}}$ & $12.3^{\mathrm{cd}}$ & $37.3^{\mathrm{e}}$ & $26^{\text {def }}$ & $31.7^{\mathrm{de}}$ & $2.6^{\mathrm{abc}}$ & $2.5^{\mathrm{bc}}$ & $2.6^{\mathrm{bcd}}$ \\
\hline$+I^{*} 30 \mathrm{~S} * 1.5 \mathrm{Zn}$ & $11.9^{\mathrm{efg}}$ & $11.4^{\mathrm{bc}}$ & $11.9^{\text {cde }}$ & $58.7^{\mathrm{a}}$ & $30.7^{\mathrm{bc}}$ & $44.7^{\mathrm{b}}$ & $2.7^{\mathrm{ab}}$ & $2.7^{\mathrm{abc}}$ & $2.7^{\mathrm{abcd}}$ \\
\hline P-value & $*$ & $* *$ & ** & ** & $* *$ & $* *$ & $*$ & $*$ & $*$ \\
\hline CV $(\%)$ & 7.12 & 8.34 & 6.31 & 5.86 & 10.39 & 5.11 & 4.41 & 7.12 & 5.1 \\
\hline
\end{tabular}

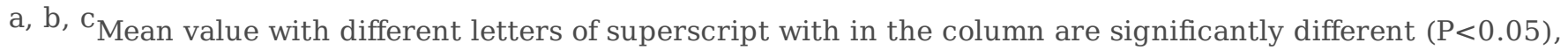
$+\mathrm{I}=$ Rhizobium inoculated, $-\mathrm{I}=$ un-inoculated, $15 \mathrm{~S}=15 \mathrm{~kg} \mathrm{~S}^{-1}, 30 \mathrm{~S}=30 \mathrm{~kg} \mathrm{~S} \mathrm{ha}^{-1}, 0 \mathrm{Zn}=0 \mathrm{~kg} \mathrm{Zn} \mathrm{ha}{ }^{-1}, 1.5 \mathrm{Zn}=1.5 \mathrm{~kg}$ Zn ha ${ }^{-1}, * *=$ significant at $1 \%, *=, 5 \%$, ns=non-significant, CV = Coefficient of variation, NNPP=nodule number per plant, NDWPP=nodule dry weight per plant, EN=effectivness of nodule.

\section{Plant height, Number of primary branch and number of pod}

The plant height which was obtained from both locations and its mean values combined over location was not significantly affected by the treatment (Table 3). Incontrast, number of primary branch and pod per plant were significantly affected by the treatment. The highest mean value of primary branches over locations (3.8) was obtained from combined application of Rhizobium inoculation and $30 \mathrm{~kg} \mathrm{Sha}^{-1}$ which resulted in $31.03 \%$ increase over the control check (Table 3). The increase in primary branches due to Rhizobial inoculation was explained by the increasing supply of $\mathrm{N}$ through BNF. Application of $\mathrm{S}$ has vital role in the primary and secondary metabolism as it is a constituent of various organic compounds 
(Hitsuda et al., 2004; Naeve and Shibles, 2005). Similarly, the number of primary branches increased due to Rhizobium inoculation and S application (Das et al., 2016; Jadeja et al., 2016; Kesare, 2014; Namvar et al., 2011; Ram and Katiyar, 2013; Sharma and Room, 1997; Togay et al., 2008) have been reported.

Similarly, The combined analysis over locations indicated that the highest (48.3) mean number of pod was obtained from combined application of Rhizobium inoculation and $30 \mathrm{~kg} \mathrm{~S} \mathrm{ha}^{-1}$. In general, the result demonstrated that number of pod per plant increased with $S$ application rate under inoculated condition with $1.5 \mathrm{~kg} \mathrm{Zn} \mathrm{ha}^{-1}$. But the trend is not consistent. The increase of number in pods per plant with applications of $\mathrm{Zn}$ might be due to the positive effect of $\mathrm{Zn}$ on formation of stamens and pollens which could increase number of pods produced in the plant (Muhammad et al., 2014). S plays many important roles in the growth and development of plants including chlorophyll and nitrogenize formation, promotes nodule formation and enzyme activation (Fageria, 2009). Similarly, El-kade and Mona (2013) reported that combined application of S and Zn increase pods number. Other researchers (Das et al., 2016; Hussain et al., 2011; Jadeja et al., 2016; Kanase et al., 2006; Kayan et al., 2015; Kesare, 2014; Namvar et al., 2011; Nasreen and Farid, 2006; Nasri et al., 2011; S. Ram and Katiyar, 2013; Togay et al., 2008; Y Zhao et al., 2008) also reported that number of pod increased with Rhizobium inoculation, $\mathrm{S}$ and $\mathrm{Zn}$ application.

Table 3.

Plant height, number of primary branch and number of pod of chickpea as affected by Rhizobium, S and Zn rates

\begin{tabular}{|c|c|c|c|c|c|c|c|c|c|}
\hline \multirow[t]{2}{*}{ Treatment } & \multicolumn{3}{|c|}{$\mathrm{PH}(\mathrm{cm})$} & \multicolumn{3}{|l|}{ NPBPP } & \multicolumn{3}{|l|}{ NPPP } \\
\hline & Tsion & Denzaz & Mean & Tsion & Denzaz & Mean & Tsion & Denzaz & Mean \\
\hline Control check & 39.2 & 34.5 & 36.9 & $3.8^{\mathrm{cde}}$ & $2.1^{\mathrm{g}}$ & $2.9^{f}$ & $48^{\mathrm{cd}}$ & $32.1^{\mathrm{ef}}$ & $40.1^{\text {def }}$ \\
\hline$-\mathrm{I}^{*} 1.5 \mathrm{Zn}$ & 39.3 & 32.3 & 35.7 & $3.4^{\mathrm{e}}$ & $3^{b c d}$ & $3.4^{\mathrm{bc}}$ & $48.4^{\mathrm{C}}$ & $34.6^{\text {cde }}$ & $41.5^{\mathrm{cde}}$ \\
\hline$-\mathrm{I} * 15 \mathrm{~S}$ & 39.2 & 30.7 & 34.9 & $3.9^{\mathrm{bcd}}$ & $3.4^{\mathrm{a}}$ & $3.4^{\mathrm{bc}}$ & $44.4^{\mathrm{fg}}$ & $35.4^{\mathrm{cd}}$ & $39.9^{\mathrm{ef}}$ \\
\hline$-I^{*} 15 \mathrm{~S} * 1.5 \mathrm{Zn}$ & 39.8 & 30.9 & 35.4 & $3.7^{\mathrm{de}}$ & $2.6^{\mathrm{ef}}$ & $3.3^{\mathrm{bcd}}$ & $45.6^{\mathrm{ef}}$ & $33.1^{\text {def }}$ & $39.3^{f}$ \\
\hline$-I * 30 S$ & 39.5 & 32.7 & 36.1 & $4.5^{\mathrm{a}}$ & $3^{\mathrm{bc}}$ & $3.3^{\mathrm{bcd}}$ & $48.2^{\mathrm{cd}}$ & $38.6^{\mathrm{b}}$ & $43.4^{\mathrm{bc}}$ \\
\hline$-I^{*} 30 \mathrm{~S} * 1.5 \mathrm{Zn}$ & 40.4 & 35.1 & 37.8 & $3.5^{\mathrm{e}}$ & $3.1^{\mathrm{b}}$ & $3.7^{\mathrm{a}}$ & $51^{\mathrm{a}}$ & $37.5^{\mathrm{bc}}$ & $44.2^{\mathrm{b}}$ \\
\hline$+\mathrm{I}$ & 36.4 & 33.9 & 35.2 & $3.5^{\mathrm{e}}$ & $2.7^{\text {cdef }}$ & $3^{\mathrm{ef}}$ & $42.9^{9}$ & $31.4^{\mathrm{f}}$ & $37.2^{\mathrm{g}}$ \\
\hline$+I^{*} 1.5 \mathrm{Zn}$ & 37.9 & 30.9 & 34.4 & $3.8^{\text {bcde }}$ & $2.5^{f}$ & $3.1^{\text {def }}$ & $46.5^{\mathrm{de}}$ & $33.3^{\text {def }}$ & $39.9^{\mathrm{ef}}$ \\
\hline$+I^{*} 15 \mathrm{~S}$ & 39 & 32.7 & 35.9 & $4.3^{\mathrm{abc}}$ & $2.5^{\mathrm{f}}$ & $3.2^{\mathrm{cde}}$ & $49.1^{\mathrm{bc}}$ & $34.9^{\text {cde }}$ & $42^{\mathrm{cd}}$ \\
\hline$+I^{*} 15 \mathrm{~S} * 1.5 \mathrm{Zn}$ & 40.6 & 33.5 & 37 & $4.2^{\mathrm{abc}}$ & $2.7^{\text {def }}$ & $3.5^{\mathrm{b}}$ & $51.3^{a}$ & $34.8^{\mathrm{cde}}$ & $43.1^{\mathrm{bc}}$ \\
\hline$+I^{*} 30 \mathrm{~S}$ & 39.6 & 33.8 & 36.7 & $3.8^{\text {bcde }}$ & $3.4^{\mathrm{a}}$ & $3.8^{\mathrm{a}}$ & $40^{\mathrm{bc}}$ & $47.7^{\mathrm{a}}$ & $48.3^{\mathrm{a}}$ \\
\hline$+\mathrm{I}^{*} 30 \mathrm{~S} * 1.5 \mathrm{Zn}$ & 40.2 & 34.7 & 37.5 & $3.7^{\mathrm{de}}$ & $2.9^{\text {bcde }}$ & $3.4^{\mathrm{bc}}$ & $50.4^{\mathrm{ab}}$ & $33^{\text {def }}$ & $41.7^{\mathrm{bc}}$ \\
\hline $\mathrm{LSD}_{0.05}$ & ns & ns & ns & $*$ & $* *$ & $* *$ & $*$ & $* *$ & $* *$ \\
\hline $\mathrm{CV}(\%)$ & 1.61 & 1.82 & 1.25 & 6.62 & 6.7 & 4.4 & 2.22 & 5.19 & 2.79 \\
\hline
\end{tabular}

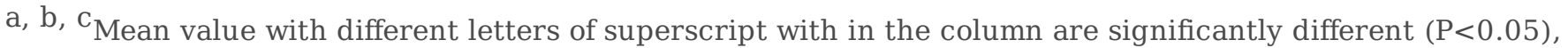
$+\mathrm{I}=$ Rhizobium inoculated, $-\mathrm{I}=$ un-inoculated, $15 \mathrm{~S}=15 \mathrm{~kg} \mathrm{~S}^{-1}, 30 \mathrm{~S}=30 \mathrm{~kg} \mathrm{~S}^{-1}, 0 \mathrm{Zn}=0 \mathrm{~kg} \mathrm{Zn} \mathrm{ha}^{-1}, 1.5 \mathrm{Zn}=1.5 \mathrm{~kg}$ $\mathrm{Zn} \mathrm{ha}{ }^{-1}, * *=$ significant at $1 \%, *=, 5 \%, \mathrm{~ns}=$ non-significant, $\mathrm{CV}=$ Coefficient of variation, $\mathrm{PH}=\mathrm{plant}$ height,

$\mathrm{NPBPP}=$ number of primary branch per plant, $\mathrm{NPPP}=$ number of pod per plant

\section{Grain yield}

Incresed chickpea grain yield due to soil fertility treatment was observed at both location and mean value combined over location (Table 3). At both sites, the highest (1515.2 at Dnzaz and $2039.8 \mathrm{~kg}$ ha at Tsion site ) seed yield was obtained from Rhizobium inoculation integrated with $30 \mathrm{~kg} \mathrm{~S} \mathrm{ha}^{-1}$ whereas the lowest at Denzaz site and mean value combined over site were from the control check. Combined over 
locations, the highest ( $\left.1777.5 \mathrm{~kg} \mathrm{ha}^{-1}\right)$ mean seed yield was obtained from the integrated application of Rhizobium and $30 \mathrm{~kg} \mathrm{~S} \mathrm{ha}^{-1}$ which resulted in $28.02 \%$ (389 kg ha-1) yield advantage over the control check (Table 3). The increase in yield might be due to the fact that $\mathrm{S}$ performs many physiological functions in cystien, methionine and chlorophyll synthesis. Rhizobium inoculation also provides adequate supply of $\mathrm{N}$ for plant and resulted in increased chlorophyll synthesis and hence photosynthetic products including grain yield. This result was in agreement with some previous finding reported on the importance of combined application of S and Rhizobium inoculation in increasing seed yield (Islam et al., 2011; Kesare, 2014; Namvar et al., 2011; Namvar and Sharifi, 2011; Rokhzadi and Toashih, 2011;

Srinivasarao et al., 2008; Togay et al., 2008; Zafar et al., 2014; Y Zhao et al., 2008; Kihara et al., 2017).

\section{Haulm yield}

Chickpea residue, locally known as "Defeka", is important as a feed resource for livestock during the dry months of the year when green fodder is unavailable (Wolde-meskel et al., 2018). At Tsion site, the highest (1398.4 kg ha-1) haulm yield was obtained from rhizobium inoculation alone while the lowest $\left(1051.2 \mathrm{~kg} \mathrm{ha}^{-1}\right)$ was from application of $1.5 \mathrm{~kg} \mathrm{Zn} \mathrm{ha}^{-1}$. At Denzaz site, the highest haulm yield (1491.2 $\mathrm{kg} \mathrm{ha}^{-1}$ ) was obtained from combined application of Rhizobium inoculation with $1.5 \mathrm{~kg} \mathrm{Zn} \mathrm{ha}^{-1}$.

Combined over locations, the highest ( $\left.1370.6 \mathrm{~kg} \mathrm{ha}^{-1}\right)$ mean haulm yield was obtained from combined application of Rhizobium inoculation and $1.5 \mathrm{~kg} \mathrm{Zn} \mathrm{ha}^{-1}$ which resulted in $27.6 \%$ Haulm yield advantage over the control check. In consistent with the current finding, Das et al. (2012) reported that Rhizobium inoculation with $10 \mathrm{~kg} \mathrm{ZnSO}_{4}$ and $25 \mathrm{~kg} \mathrm{ZnSO}_{4}$ ha $^{-1}$ resulted in increased haulm yield. Similar result were concluded by Sipai et al. (2016) and Pable et al. (2010) who found positive role of Rhizobium inoculation and $\mathrm{Zn}$ application on Haulm yield for mungbean and soybean, respectively. Srivastava et al. (2006) also reported that the combined application of rhizobium inoculation with $30 \mathrm{~kg} \mathrm{~S}$ and $5 \mathrm{~kg} \mathrm{Zn} \mathrm{ha-1}$ increase haulm yield of summer green gram.

\section{Table 4.}

Grain and Haulm yield as affected by Rhizobium, S and Zn rates 


\begin{tabular}{|c|c|c|c|c|c|c|}
\hline \multirow[t]{2}{*}{ Treatment } & \multicolumn{3}{|c|}{ Grain yield $\left(\mathrm{kg} \mathrm{ha}^{-1}\right)$} & \multicolumn{3}{|c|}{ Haulm yield $\left(\mathrm{kg} \mathrm{ha}^{-1}\right)$} \\
\hline & Tsion & Denzaz & Mean & Tsion & Denzaz & Mean \\
\hline Control check & $1756.5^{\text {cde }}$ & $1020.5^{f}$ & $1421.8^{\mathrm{fg}}$ & $1160.1^{d}$ & $987.8^{\mathrm{e}}$ & $1074^{\mathrm{f}}$ \\
\hline$-I^{*} 1.5 \mathrm{Zn}$ & $1726.6^{\mathrm{de}}$ & $1265.6^{\mathrm{cde}}$ & $1568.6^{\text {cde }}$ & $1051.2^{\mathrm{e}}$ & $1212.1^{\mathrm{cd}}$ & $1131.7^{\mathrm{ef}}$ \\
\hline$-\mathrm{I} * 15 \mathrm{~S}$ & $1963.5^{\mathrm{ab}}$ & $1307.2^{\mathrm{bcde}}$ & $1539.9^{\text {def }}$ & $1269^{b c}$ & $1206.2^{\mathrm{cd}}$ & $1237.6^{\mathrm{cd}}$ \\
\hline -I*15S*1.5Zn & $1936.2^{\mathrm{abc}}$ & $1307.2^{\mathrm{e}}$ & $1666.3^{\mathrm{abcd}}$ & $1228.2^{\mathrm{cd}}$ & $1247.7^{\mathrm{abc}}$ & $1238^{\mathrm{abc}}$ \\
\hline$-I * 30 S$ & $1963.5^{\mathrm{ab}}$ & $1405.2^{\mathrm{abcd}}$ & $1777.5^{\mathrm{a}}$ & $1334.4^{\mathrm{ab}}$ & $1390.3^{\mathrm{ab}}$ & $1362.4^{\mathrm{a}}$ \\
\hline$-\mathrm{I} * 30 \mathrm{~S} * 1.5 \mathrm{Zn}$ & $1919.9^{\mathrm{abc}}$ & $1482.4^{\mathrm{ab}}$ & $1552.3^{\text {cdef }}$ & $1236.4^{\mathrm{bcd}}$ & $1339.9^{\mathrm{bcd}}$ & $1288.1^{\mathrm{abc}}$ \\
\hline$+\mathrm{I}$ & $1693.2^{\mathrm{e}}$ & $1150.3^{\mathrm{ef}}$ & $1388.5^{\mathrm{g}}$ & $1398.4^{\mathrm{a}}$ & $1015.4^{\mathrm{e}}$ & $1206.9^{\text {de }}$ \\
\hline$+I^{*} 1.5 \mathrm{Zn}$ & $1895.4^{\mathrm{abcd}}$ & $1241.8^{\mathrm{de}}$ & $1496.1^{\text {efg }}$ & $1250^{\mathrm{bcd}}$ & $1491.2^{\mathrm{a}}$ & $1370.6^{\mathrm{a}}$ \\
\hline$+I^{*} 15 S$ & $1775.6^{\text {cde }}$ & $1304.2^{\mathrm{bcde}}$ & $1635.4^{\mathrm{abcd}}$ & $1190.1^{\mathrm{cd}}$ & $1369.6^{\mathrm{ab}}$ & $1279.8^{\mathrm{bcd}}$ \\
\hline$+I^{*} 15 \mathrm{~S} * 1.5 \mathrm{Zn}$ & $1903.6^{\mathrm{abcd}}$ & $1429^{\mathrm{abc}}$ & $1621.7^{\mathrm{abcd}}$ & $1239.1^{\mathrm{bcd}}$ & $1194.3^{\mathrm{d}}$ & $1216.7^{\text {cde }}$ \\
\hline$+I^{*} 30 \mathrm{~S}$ & $2039.8^{\mathrm{a}}$ & $1515.2^{\mathrm{a}}$ & $1684.4^{\mathrm{abc}}$ & $1334.4^{\mathrm{ab}}$ & $1375.5^{\mathrm{abc}}$ & $1355^{\mathrm{a}}$ \\
\hline$+\mathrm{I} * 30 \mathrm{~S} * 1.5 \mathrm{Zn}$ & $1797.4^{\text {bcde }}$ & $1307.2^{\text {bcde }}$ & $1701.2^{\mathrm{ab}}$ & $1171^{\mathrm{cd}}$ & $1209.2^{\mathrm{cd}}$ & $1190.1^{\mathrm{de}}$ \\
\hline P-value & $*$ & $*$ & $*$ & ns & ** & $*$ \\
\hline$\overline{C V(\%)}$ & 5.85 & 8.45 & 4.94 & 5 & 7.14 & 4.27 \\
\hline
\end{tabular}

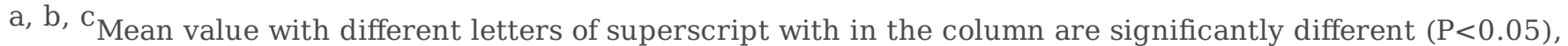
$+\mathrm{I}=$ Rhizobium inoculated, $-\mathrm{I}=$ un-inoculated, $15 \mathrm{~S}=15 \mathrm{~kg} \mathrm{~S} \mathrm{ha}^{-1}, 30 \mathrm{~S}=30 \mathrm{~kg} \mathrm{~S}^{-1}, 0 \mathrm{Zn}=0 \mathrm{~kg} \mathrm{Zn} \mathrm{ha}{ }^{-1}, 1.5 \mathrm{Zn}=1.5 \mathrm{~kg}$ Zn ha ${ }^{-1}, * *=$ significant at $1 \%, *=, 5 \%$, ns=non-significant, CV $=$ Coefficient of variation.

\section{Total nitrogen uptake}

Total $\mathrm{N}$ uptake of legume can serve as a good indicator of N2 fixation. Total N uptake was significantly improved with the fertility treatment (Table 4). The highest total $\mathrm{N}$ uptake $\left(67.4 \mathrm{~kg} \mathrm{ha}^{-1}\right)$ was generally observed in Tsion kebele. This was expalined by the fact that highest biological yield also observed in this kebele. The total $\mathrm{N}$ uptake of this site varied from 67.4 to $49.8 \mathrm{~kg} \mathrm{ha}^{-1}$ with Rhizobium inoculation when integrated with $30 \mathrm{~kg} \mathrm{~S}$ and $1.5 \mathrm{~kg} \mathrm{Zn} \mathrm{ha}^{-1}$ and control check, respectively. At Denzaz site, the highest (52.4 $\mathrm{kg} \mathrm{N} \mathrm{ha}^{-1}$ ) and lowest $\left(30.8 \mathrm{~kg} \mathrm{~N} \mathrm{ha}^{-1}\right)$ total $\mathrm{N}$ uptake was recorded in response the Rhizobium inoculation applied with $30 \mathrm{~kg} \mathrm{~S} \mathrm{ha}^{-1}$ and at the control check, respectively. The combined analysis over location indicated that, the highest $\left(58.7 \mathrm{~kg} \mathrm{ha}^{-1}\right)$ total $\mathrm{N}$ uptake were recorded when Rhizobium was inoculated with, $30 \mathrm{~kg} \mathrm{~S}$ and $1.5 \mathrm{~kg} \mathrm{Zn} \mathrm{ha}^{-1}$, which resulted in $45.7 \%$ increase over the control check.

This increment could be attributed to Rhizobium inoculation helped in biological nitrogen fixation and thus, increase $\mathrm{N}$ content in grain and haulm. The increase in $\mathrm{N}$ uptake as a result of $\mathrm{S}$ application might be due to an increment in protein synthesis and enhance photosynthesis (Yanwen Zhao et al., 2008). In the absence of $\mathrm{S}$, amino acids cannot be transformed into proteins, which results in reduced $\mathrm{N}$ acquisition (Varin et al., 2009). Zn is involved in auxin metabolism like, tryptophane synthesis, tryptamine metabolism, protein synthesis, formation of nucleic acid and helps in utilization of nitrogen as well as phosphorus by plants (Ram and Katiyar, 2013). Similar to the current findings $N$ uptake increase due to rhizobium inoculation, S and Zn application have been reported by several literatures (Abdalla et al., 2011; Das et al., 2016; Desta et al., 2015; El-kade and Mona, 2013; Hussain et al., 2011; Islam et al., 2013; Jay et al., 2012; Kesare, 2014; Mondal et al., 2005; Najar et al., 2011; Rokhzadi and Toashih, 2011; Shamima and Farid, 2006; Srinivasulu et al., 2015; Srivastava et al., 2006; Togay et al., 2008; Zaidi et al., 2003; Zerihun et al., 2017) 


\section{Total phosphorus uptake}

The analysis of variance showed that, application of $\mathrm{S}$ with inoculation and $\mathrm{Zn}$ were found to be significant (Table 4). At Tsion and mean value over locations, the highest and lowest total P uptakes were found due to combined application of $30 \mathrm{~kg} \mathrm{~S}$ with $1.5 \mathrm{~kg} \mathrm{Zn} \mathrm{ha}^{-1}$ and Rhizobium inoculation, respectively. At Denzaz, the highest $\left(10.5 \mathrm{~kg} \mathrm{ha}^{-1}\right)$ total $\mathrm{P}$ uptake was obtained with sole application of 30 $\mathrm{kg} \mathrm{S} \mathrm{ha}^{-1}$. The highest mean total P uptake increase by $65.7 \%$ over the control check. This could be due to the fact that $S$ application increases $P$ availability in the soil by which enhance the $P$ uptake by plant (Fageria, 2009). The increse in $P$ uptake in the present study agree with earlier findings reported by; Togay et al. (2008), Najar et al. (2011), Yadav (2011), Islam et al. (2013), Kesare (2014), Das et al. (2016), Srinivasulu et al. (2015), Zerihun et al. (2017).

Table 5.

Total $\mathrm{N}$ and $\mathrm{P}$ uptake as affected by Rhizobium, $\mathrm{S}$ and $\mathrm{Zn}$ fertilizer rates

\begin{tabular}{|c|c|c|c|c|c|c|}
\hline \multirow[t]{2}{*}{ Treatment } & \multicolumn{3}{|c|}{ TNU $\left(\mathrm{kg} \mathrm{ha}{ }^{-1}\right)$} & \multicolumn{3}{|c|}{ TPU (kg ha-1) } \\
\hline & Tsion & Denzaz & Mean & Tsion & Denzaz & Mean \\
\hline Control check & $49.8^{g}$ & $30.8^{\mathrm{i}}$ & $40.3^{9}$ & $8.4^{\mathrm{f}}$ & $8.4^{\mathrm{f}}$ & $8.4^{\mathrm{f}}$ \\
\hline -I*1.5Zn & $52.3^{\mathrm{fg}}$ & $39.7^{\mathrm{g}}$ & $46^{f}$ & $9.1^{\mathrm{e}}$ & $9.1^{\mathrm{e}}$ & $9.1^{\mathrm{e}}$ \\
\hline$-I * 15 S$ & $60^{\mathrm{bcd}}$ & $43.6^{\mathrm{ef}}$ & $51.8^{\mathrm{e}}$ & $12^{\mathrm{b}}$ & $12^{\mathrm{b}}$ & $12^{\mathrm{b}}$ \\
\hline -I*15S*1.5Zn & $61.5^{\mathrm{bc}}$ & $44.1^{\mathrm{ef}}$ & $52.8^{\mathrm{de}}$ & $11.3^{\mathrm{c}}$ & $11.3^{\mathrm{c}}$ & $11.3^{\mathrm{c}}$ \\
\hline$-I * 30 S$ & $61.5^{\mathrm{bc}}$ & $48.6^{\mathrm{bc}}$ & $55^{\mathrm{cd}}$ & $12.7^{b}$ & $12.7^{b}$ & $12.7^{\mathrm{b}}$ \\
\hline -I*30S*1.5Zn & $64.6^{\mathrm{ab}}$ & $51.3^{\mathrm{a}}$ & $58^{a b}$ & $13.2^{\mathrm{a}}$ & $13.2^{\mathrm{a}}$ & $13.2^{\mathrm{a}}$ \\
\hline$+\mathrm{I}$ & $56.6^{\text {def }}$ & $35.6^{\mathrm{h}}$ & $46.1^{\mathrm{f}}$ & $8.2^{\mathrm{f}}$ & $8.2^{\mathrm{f}}$ & $8.2^{\mathrm{f}}$ \\
\hline$+\mathrm{I}^{*} 1.5 \mathrm{Zn}$ & $53.4^{\mathrm{efg}}$ & $41.6^{\mathrm{fg}}$ & $47.5^{f}$ & $8.6^{\mathrm{ef}}$ & $8.6^{\mathrm{ef}}$ & $8.6^{\mathrm{ef}}$ \\
\hline$+I^{*} 15 \mathrm{~S}$ & $60.4^{\mathrm{bcd}}$ & $45.6^{\mathrm{de}}$ & $53^{\text {cde }}$ & $10.8^{\mathrm{cd}}$ & $10.8^{\mathrm{cd}}$ & $10.8^{\mathrm{cd}}$ \\
\hline$+\mathrm{I} * 15 \mathrm{~S} * 1.5 \mathrm{Zn}$ & $57.3^{\text {cde }}$ & $47.4^{\mathrm{cd}}$ & $52.3^{\text {bde }}$ & $11^{\mathrm{cd}}$ & $11^{\mathrm{cd}}$ & $11^{\mathrm{cd}}$ \\
\hline$+\mathrm{I} * 30 \mathrm{~S}$ & $58.4^{\mathrm{cd}}$ & $52.4^{\mathrm{a}}$ & $55.4^{\mathrm{bc}}$ & $10.7^{\mathrm{d}}$ & $10.7^{\mathrm{d}}$ & $10.7^{d}$ \\
\hline$+\mathrm{I}^{*} 30 \mathrm{~S} * 1.5 \mathrm{Zn}$ & $67.4^{\mathrm{a}}$ & $50.1^{\mathrm{ab}}$ & $58.7^{\mathrm{a}}$ & $12.5^{b}$ & $12.5^{b}$ & $12.5^{\mathrm{b}}$ \\
\hline P-value & $* *$ & $*$ & $*$ & $*$ & ** & * \\
\hline$\overline{\mathrm{CV}}(\%)$ & 4.88 & 3.21 & 2.95 & 3 & 3 & 3 \\
\hline
\end{tabular}

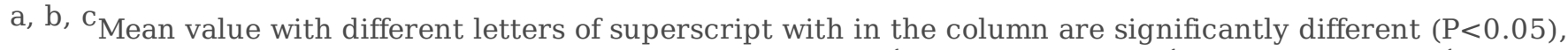
$+\mathrm{I}=$ Rhizobium inoculated, $-\mathrm{I}=$ un-inoculated, $15 \mathrm{~S}=15 \mathrm{~kg} \mathrm{~S}^{-1}, 30 \mathrm{~S}=30 \mathrm{~kg} \mathrm{~S}^{-1}, 0 \mathrm{Zn}=0 \mathrm{~kg} \mathrm{Zn} \mathrm{ha}{ }^{-1}, 1.5 \mathrm{Zn}=1.5 \mathrm{~kg}$ Zn ha ${ }^{-1}, * *=$ significant at $1 \%, *=, 5 \%$, ns=non-significant, CV $=$ Coefficient of variation, TNU=total nitrogen uptake, TPU =total phosphrus uptake

\section{P use efficiency}

The result also demonstrated that at both locations, the highest $\mathrm{P}$ use efficiency $(77.3 \%$ at Tsion and $163.6 \%$ at Denzaz site) were obtained with Rhizobium inoculation which resulted in $31 \%$ and $45.3 \%$ increase over the un-inoculated treatment (Fig. 4A). Application of $15 \mathrm{~kg} \mathrm{~S} \mathrm{ha}^{-1}$ also caused the highest $\mathrm{P}$ use efficiency and it increased P use efficiency by $12.6 \%$ over $S$ control (Fig. 4B). The increase in P use efficiency due to Rhizobium inoculation and $\mathrm{S}$ application could be due to the need of high P for ATP synthesis as result of high BNF activity and increase the $\mathrm{P}$ availability due to $\mathrm{S}$ application. In contrast to this, Zn application did not affect $P$ use efficiency (Fig. 4C). This could be attributed to the fact that application of $\mathrm{Zn}$ to plants grown in $\mathrm{Zn}$ deficient soils is effective in reducing uptake and accumulation of $\mathrm{P}$ (and phytate) in plants (Mousavi et al., 2012). 


\section{Conclusion}

In general, the use of effective rhizobia in combination with $\mathrm{Zn}$ and $\mathrm{S}$ in the both study sites increase the nodulation, yield and NP uptake and use efficacy of chickpea. Combined application of rhizobia and S could be the recommended for the integrated nutrient management for chickpea production in the study site.

\section{Acknowledgement}

This work was financially supported by International Livestock Research Institute/N2 Africa (ILRI/N2) and Amhara Regional Agricultural Research Institute (ARARI). We are grateful to Debre Birhan and Gondar Agricultural Research Center, Haramaya University staff members for their support starting from site selection to preparation of the manuscript. The authors would also like to acknowledge ILRI/N2A staff members.

\section{Reference}

Abdalla, A.S., Osman, A.G., Abdelgani, M., Rugheim, A.M.E., 2011. Effects of biological and mineral fertilization on nodulation, nitrogen and phosphorus content and yield of chickpea (Cicer arietinum L.). Adv. Environ. Biol. 5, 2886-2894.

Adjei, M.B., Quesendberry, K.H., Chambliss, C.G., 2001. Nitrogen Fixation and Inoculation of Forage Legumes. Thail. J. Agric. Res. 14, 143-147.

Ahlawat, I.P., Ali, M., 1993. Fertilizer management in food crops. FDCO, New Delhi.

Ahlawat, I.P.S., Gangaiah, B., Ashraf Zadid, M., 2007. Nutrient management in chickpea, in: Yadav, S.., Redden, R., Chen, W., Sharma, B. (Eds.), Chickpea Breeding and Management. CAB International, Wallingford, Oxon, UK., pp. 213-232.

Alloway, B.J., 2008. Zinc in soils and crop nutrition, Second. ed. IZA and IFA, Brussels, Belgium and Paris, France.

Argaw, A., Muleta, D., 2016. Inorganic nitrogen application improves the yield and yield traits of common bean (Phaseolus vulgaris L.) irrespective of the indigenous rhizobial population. South African J. Plant Soil. https://doi.org/10.1080/02571862.2016.1193906.

Bagayoko, M., Maman, N., Palé, S., Sirifi, S., Taonda, S.J.B., Traore, S., Mason, S.C., 2011. Microdose and $\mathrm{N}$ and $\mathrm{P}$ fertilizer application rates for pearl millet in West Africa. African J. Agric. Res. 6, 1141-1150.

Belay, 2006. Cereals and pulses. Wageningen, Netherlands. 
Berhanu, D., 1985. The Vertisols of Ethiopia: their properties, classification and management, in: Fifth Meeting of the Eastern African Sub-Coimiitree for Soil Correlation and Land Evaluiarion. Wad Medani, Sudan,. pp. 31-54.

Beyene, D., 1988. Biological Nitrogen Fixation Research on Grain Legumés in Ethiopia-An Overview, in: Nitrogen Fixation by Legumes in Mediterranean Agriculture. Springer, pp. 73-78.

Cakmak, I., Torun, B., Erenoglu, B., Kalaycl, M., Yılmaz, A., Ekiz, H., Braun, H., 1995. Türkiye'de toprak ve bitkilerde çinko eksikliği ve bitkilerin çinko eksikliğine dayanıklılık mekanizmaları. Türk Tarım ve Ormancılık Dergisi, Ankara. Ankara.

Choudhry, M., 2012. Growth, yield and nitrogen content of lentil (lens culinaris medic) as affected by nitrogen and diquat application (PhD Thesis).

Corp, M., Machado, S., Ball, D., Smiley, R., Petrie, S., Siemens, M., Guy, S., 2004. Chickpea Production Guide $1-14$.

CSA(Central Statistical Agency), 2014. Agricultural sample survey. Report on area and production of major crops (private peasant holdings, meher season).

Das, S.., Biswas, B., Jana, K., 2016. Effect of farm yard manure, phosphorus and sulphur on yield parameters, yield, nodulation, nutrient uptake and quality of chickpea (Cicer arietinum L.). J. Appl. Nat. Sci. $8,545-549$.

Das, S., Pareek, N., Raverkar, K.P., Chandra, R., Kaustav, A., 2012. Effectiveness of micronutrient application and Rhizobium inoculation on growth and yield of Chickpea. Int. J. Agric. Environment Biotechnology 5, 445-452.

Desta, B., 1982. Diagnosis of phosphorus deficiency in Ethiopian soils., in: Soil Science Bulletin. IAR (Institute of Agriculture), Addis Ababa, Ethiopia, pp. 1-23.

Desta, Y., Habtegebrial, K., Weldu, Y., 2015. Inoculation, phosphorous and zinc fertilization effects on nodulation, yield and nutrient uptake of Faba bean (Vicia faba L .) grown on calcaric cambisol of semiarid Ethiopia 6, 9-15. https://doi.org/10.5897/JSSEM2013.0406.

El-kade, A., Mona, G., 2013. Effect of Sulfur Application and Foliar Spraying with Zinc and Boron on Yield, Yield Components, and Seed Quality of Peanut. Res. J. Agric. Biol. Sci. 9, 127-135.

EthioSIS (Ethiopian Soil Information System), 2016. Soil fertility status and fertilizer recommendation atlas of Amhara national regional state, Ethiopia. Addis Abeba, Ethiopia.

Fageria, N.K., 2009. The use of nutrient in crop plant. Boca Raton, FL: CRC Press. 
Fageria, N.K., Santos, A.B., 2002. Low land rice genotypes evaluation for phosphorus use efficiency. J. Plant Nutr. 25, 2793-2802. https://doi.org/doi: 10.1081/PLN-120015539.

Fanuel, L., 2015. Soil spatial variability analysis, fertility mapping and soil plant nutrient relations in Wolaita zone, Southern Ethiopia. Haramaya University.

Fassil, K., Charles, Y.C., 2009. Soil fertility status and numass fertilizer recommendation of typic hapluusterts in the Northern highlands of Ethiopia. World Appl. Sci. J. 6, 1473-1480.

Fatima, Z., Zia, M., Chaudhary, M.., 2007. Interactive effect of Rhizobium strains and P on soybean yield, nitrogen fixation and soil fertility. Pakistan J. Bot. 39, 255-264.

Funga, A., Ojiewo, C.O., Turoop, L., Mwangi, G.S., 2016. Symbiotic Effectiveness of Elite Rhizobia Strains Nodulating Desi Type Chickpea (Cicer arietinum L .) Varieties 4, 88-94.

https://doi.org/10.11648/j.jps.20160404.15.

Ganeshamurthy, A.N., Sammi Reddy, K., 2000. Effect of integrated use of farmyard manure and sulphur in a soybean and wheat cropping system on nodulation, dry matter production and chlorophyll content of soybean on swell-shrink soils in Central India. J. Agron. Crop Sci. 185, 91-97. https://doi.org/10.1046/j.1439-037X.2000.00403.x.

Goa, Y., 2014. Evaluation of Chickpea (Cicer arietinum L .) Varieties for Yield Performance and Adaptability to Southern Ethiopia. J. Biol. Agric. Healthc. 4, 34-39.

Gomez, A.K., Gomez, A.A., 1984. Statistical procedure for Agricultural Research, (2nd ed.). ed. John Wiley and Sons, New York.

GOZOARD (Gonder Zuria Office of Agriculture and Rural Development), 2016. Annual report. Maksegnit.

Habbasha, S.F. El, Mohamed, M.H., El-lateef, E.M.A., Mekki, B.B., Ibrahim, M.E., 2013. Effect of Combined Zinc and Nitrogen on Yield, Chemical Constituents and Nitrogen Use Efficiency of Some Chickpea Cultivars under Sandy Soil Conditions 9, 354-360. https://doi.org/10.5829/idosi.wjas.2013.9.4.1761.

Habtamu, A., Heluf, G., Bobe, B., Enyew, A., 2014. Fertility status of soils under different land uses at Wujiraba watershed, North-western highlands of Ethiopia. Agric. For. Fish. 3, 410-419.

https://doi.org/10.11648/j.aff.20140305.24.

Haileselassie, B., Stomph, T.-J., Hoffland, E., 2011. Teff ( Eragrostis tef ) production constraints on Vertisols in Ethiopia: farmers' perceptions and evaluation of low soil zinc as yield-limiting factor. Soil Sci. Plant Nutr. 57, 587-596. https://doi.org/10.1080/00380768.2011.593482.

Hailu, H., Mamo, T., Keskinen, R., Karltun, E., Gebrekidan, H., Bekele, T., 2015. Soil fertility status and wheat nutrient content in Vertisol cropping systems of central highlands of Ethiopia. Agric. Food Secur. 4, 19. https://doi.org/10.1186/s40066-015-0038-0. 
Hazelton, P.A., Murphy, B.W., 2007. Interpreting soil test results: what do all the numbers mean? CSIRO Publishing, Collingwood, Australia.

Hitsuda, K., Sfredo, G.J., Klepker, D., 2004. Diagnosis of sulphur deficiency in soybean using seeds. Soil Sci. Soc. Am. J. 68, 1445-1451.

Hussain, K., Islam, M., Siddique, M.T., Hayat, R., Mohsan, S., 2011. Soybean growth and nitrogen fixation as affected by sulfur fertilization and inoculation under rainfed conditions in Pakistan. Int. J. Agric. Biol. $13,951-955$.

IFPRI (International Food Policy Research Institute), 2015. Woreda-level crop production rankings in Ethiopia: A pooled data. Addis Ababa, Ethiopia.

Islam, M., Mohsan, S., Afzal, S., Ali, S., Akmal, M., Khalid, R., 2011. Phosphorus and sulphur application improves the chickpea productivity under rainfed conditions. Int. J. Agric. Biol. 13, 713-718.

Islam, M., Mohsan, S., Ali, S., Islam, M., Mohsan, S., Ali, S., 2013. Interactive Effect of Sulfur and Phosphorus on Nodulation, Nitrogen Fixation, and Nutrient Uptake by Chickpea Grown on Calcareous Soils in Pakistan 4167. https://doi.org/10.1080/01904167.2013.805220.

Jadeja, A.S., Rajani, A. V, Foram, C., Kaneriy, A.S.C., Kavar, N.R., 2016. Soil application of potassium and sulphur and effect on growth and yield components of chickpea (Cicer arietinum L.) under South Saurashtra Region of Gujarat. Int. J. Sci. Environ. Technol. 5, 3172-3176.

Jay, P., Janardan, Y., Kavindra, N.T., 2012. Enhancement of nodulation and yield of chickpea by coinoculation of indigenous Mmesorhizobium spp. and plant growth promoting rhizobacteria in eastern uttar pradesh. Commun. Soil Sci. Plant Anal. 43, 605-621.

https://doi.org/10.1080/00103624.2012.639110.

Kamara, C.S., Haque, I., Beyene, D., 1989. Characteristics of soils at the IAR research sub-centres at Sheno and Ginchi. Addis Ababa, Ethiopia.

Kanase, N., Jadhao, S.M., Konde, N.M., Patil, J.D., 2006. Response of soybean to application of zinc in Inceptisol. Ann. Pl. Phy 20, 135-136.

Kassie, M., Shiferaw, B., Asfaw, S., Abate, T., Muricho, G., Ferede, S., Eshete, M., Assefa, K., 2009. Current Situation and Future Outlooks of the Chickpea Sub - sector in Ethiopia.

Kayan, N., Gulmezoglu, N., Kaya, M.D., 2015. The optimum foliar zinc source and level for improving Zn content in seed of chickpea. Legum. Res. - An Int. J. 38. https://doi.org/10.18805/Ir.v38i6.6731.

Kesare, V.K., 2014. Effect of levels of sulphur on nutrient uptake, yield and quality of soybean in Inceptisol. MSc Thesis,. Kolhapur College of agriculture, India. 
Kihara, J., Sileshi, G.W., Nziguheba, G., Kinyua, M., Zingore, S., Sommer, R., 2017. Application of secondary nutrients and micronutrients increases crop yields in sub-Saharan Africa.

https://doi.org/10.1007/s13593-017-0431-0.

Landon, J.R., 1991. Booker tropical soil manual:A Handbook for Soil Survey and Agricultural Land Evaluation in the Tropics and Subtropics. Longman Scientific and Technical Group, UK Ltd, New York.

Lee, J.-Y., Song, S.-H., 2007. Evaluation of groundwater quality in coastal areas: implications for sustainable agriculture. Environ. Geol. 52, 1231-1242.

Lelago, A., Tekalign, M., Wassie, H., Hailu, S., 2016. Assessment and mapping of status and spatial distribution of soil macronutrients in Kambata Tembaro Zone, Southern Ethiopia. Adv. Plants Agric. Res. 4. https://doi.org/doi: 10.15406/apar.2016.04.00144.

Lemma, G., Smit, G., 2008. Relationships between plant and soil nutrient status and position in the landscape on Pellic Vertisols of Ethiopia. South African J. Plant soil 25, 119-126.

Lewis, D.C., 1999. Sulphur, in: Peverill, K.I., Sparrow, L.A., Reuter, D.J. (Eds.), Soil Analysis: An Interpretation Manual. CSIRO Publishing, Collingwood, Australia., pp. 221-228.

Lindsay, W.L., Norvell, W.A., 1978. Development of a DTPA soil test for zinc, iron, manganese, and copper. Soil Sci. Soc. Am. Journal. Soc. Am. J., 42, 421-428.

Meen, B.., Pareek, B.., Kumar, R., Singh, A.., 2010. Response of moth bean (Vigna acontifolia) cultivars on different levels of phosphrus. Environ. Ecol. 28, 2614-2617.

Mengel, K., Kirkby, E.A., 1987. Principles of Plant Nutrition, 4th Edn. International Potash Institute, Horgen, Switzerland., 4th ed. International Potash Institute, Horgen, Switzerland.

Mesfin, A., 1998. Nature and management of Ethiopian soils. Alemaya University of agriculture, Alemaya, Ethiopia, pp. 272.

Mondal, S.S., Mandal, P., Saha, M., Bag, A., Nayak, S., Sounda, G., 2005. Effect of potassium and sulphur on the productivity, nutrient uptake and quality improvement of chickpea. J. Crop weed 2, 64-66.

Mortenson, L.E., Thorneley, R.N., 1979. Structure and Function of Nitrogenase. Annu. Rev. Biochem 48, 387-418.

Mousavi, S.R., Galavi, M., Rezaei, M., 2012. The interaction of zinc with other nutrients in plants: a review. Int. J. Agric. Crop Sci. 4, 1881-1884.

Muhammad, U., Muhammad, T., Muhammad, A.M., 2014. Effect of Zinc Sulphate as Soil Application and Seed Treatment on Green Gram (Vigna radiata L.). Pakistan J. Life Soc. Sci. 12, 87-91. 
Naeve, S.L., Shibles, R.M., 2005. Distribution and mobilization of sulphur during soybean reproduction. Crop Sci. 45, 2540-2551.

Najar, G.R., Singh, S.R., Akhtar, F., Hakeem, S.A., 2011. Influence of sulphur level on yield, uptake quality of soybean (Glycine max) under temperate conditions of Kashmir valley. Indian J. Agric. Res. 81, 343-3.

Namvar, A., Sharifi, R.S., 2011. Growth analysis and yield of chickpea (Cicer arietinum L .) in relation to organic and inorganic nitrogen fertilization $57,97-108$.

Namvar, A., Sharifi, R.S., Sedghi, M., Zakaria, R.A., Khandan, T., Eskandarpour, B., 2011b. Study on the Effects of Organic and Inorganic Nitrogen Fertilizer on Yield, Yield Components, and Nodulation State of Chickpea (Cicer arietinum L.). Commun. Soil Sci. Plant Anal. 42, 1097-1109. https://doi.org/10.1080/00103624.2011.562587.

Nasreen, S., Farid, A.T.M., 2006. Sulphur uptake and yield of soybean as influenced by sulphur fertilization. Pakistan J. Agric. Res. 19, 59.

Nasri, M., Khalatbari, M., Farahani, H.A., 2011. Zn-foliar Application Influence on Quality and Quantity Features in Phaseolous 5, 839-846.

Pable, D., Paul, D.B., Deshmukh, P.W., 2010. Effect of sulphur and zinc on yield and quality of soybean. Asian J. Soil Sci. 5, 315-317.

Pathak, G.C., Gupta, B., Pandey, N., 2012. Improving reproductive efficiency of chickpea by foliar application of zinc. Brazilian Soc. Plant Physiol. 24, 173-180.

Ram, S., Katiyar, T.P.S., 2013. Effect of sulphur and zinc on the seed yield and protein content of summer mungbean under arid climate. Int. J. Sci. Nat. 4, 563-566.

Rigby, D., Cáceres, D., 2001. Organic farming and the sustainability of agricultural systems. Agric. Syst. $68,21-40$.

Rokhzadi, A, Toashih, V., 2011. Nutrient uptake and yield of chickpea (Cicer arietinum L.) inoculated with plant growth promoting rhizobacteria. Aust. J. Crop Sci. 5, 44-48.

Roy, R.N., Finck, A., Blair, G.J., Tandon, H.L.S., 2006. Plant nutrition for food security. A guide for integrated nutrient management. FAO Fertilizer and Plant Nutrition Bulletin 16. Rome, Italy.

Scherer, H.W., Pacyna, S., Spoth, K.R., Schulz, M., 2008. Low Levels of Ferredoxin, ATP and Leghemoglobin Contribute to Limited N2 Fixation of Peas (Pisum Sativum L.) and Alfalfa (Medicago Sativa L.) under S Deficiency Conditions. Biol. Fertil. Soils 44, 909-916.

Shamima, N., Farid, A.T.M., 2006. Sulphur uptake and yield of soybean as influenced by sulphur fertilization. Pakistan J. Agric. Res. 19, 59-64. 
Sharma, M.P., Room, S., 1997. Effect of phosphorus and sulphur on green gram (Phaseolus radiates). Indian J. Agron. 42, 650-652.

Singleton, P.W., Tavares, J.W., 1986. Inoculation Response of Legumes in Relation to the Number and Effectiveness of Indigenous Rhizobium Populations 51, 1013-1018.

Sipai, A.H., Jat, J.R., Rathore, B.S., 2016. Effect of Phosphorus, Sulphur and Biofertilizer on Growth, Yield and Nodulation in Mungbean on Loamy Sand Soils of Kutch. Crop Res. 51.

Slattery, J.F., Pearce, D.J., Slattery, W.J., 2004. Effects of resident rhizobial communities and soil type on the effective nodulation of pulse legumes $36,1339-1346$. https://doi.org/10.1016/j.soilbio.2004.04.015.

Somasegaran, P., Hoben, J.H., 1994. Handbook for Rhizobia: methods in legume-Rhizobium technology. Springer, Berlin Heidelberg New York.

Srinivasarao, C.H., Wani, S.P., Sahrawat, K.L., Rego, T.J., Pardhasaradhi, G., 2008. zinc, boron and sulphur deficiencies are holding back the potential of rainfed crops in semi-arid India: Experiences from participatory watershed management. Int. J. Plant Prod. 2, 89-99.

Srinivasulu, D. V, Solanki, R.M., Kumari, C.R., Babu, M.V.S., 2015. Nutrient uptake, yield and protein content of chickpea (Cicer arietinum $\mathrm{L}$.) as influenced by irrigation and sulphur levels in medium black soils 11 , 54-58. https://doi.org/10.15740/HAS/IJAS/11.1/54-58.

Srivastava, A.K., Tripathi, P.N., Singh, A.K., Singh, R., 2006. Effect of rhizobium inoculation, sulphur and zinc on growth, yield, nutrient uptake and quality of summer green gram (Phaseolus aureus L.). Indian J. Agric. Sci. 2, 190-192.

Tekalign, T., 1991. Soil, plant, water, fertilizer, animal manure and compost analysis (No. 3). Addis Ababa, Ethiopia.

Tena, W., Wolde-Meskel, E., Walley, F., 2016. Response of chickpea (Cicer arietinum L.) to inoculation with native and exotic Mesorhizobium strains in Southern Ethiopia. African J. Biotechnol. 15, 1920-1929. https://doi.org/10.5897/AJB2015.15060.

Togay, N., Togay, Y., Cimrin, K.M., Turan, M., 2008. Effects of rhizobium inoculation, sulfur and phosphorus applications on yield, yield components and nutrient uptakes in chickpea (Cicer arietinum L .) 7, 776-782. https://doi.org/10.5897/AJB07.892.

Varin, S., Leveel, S., Lavenant, L., Cliquet, J.B., 2009. Does the white clover response to sulphur availability correspond to phenotypic or ontogenetic plasticity? Acta Oecologica 35, 452-457.

Wolde-meskel, E., 2007. Genetic Diversity of Rhizobia in Ethiopian Soil: their Potential to Enhance Biological Nitrogen Fixation (BNF) and Soil Fertility for Sustainable Agriculture. Ethi. J. Biol. Sci 6, 77-95. 
Wolde-meskel, E., Heerwaarden, J. Van, Abdulkadir, B., 2018. Additive yield response of chickpea (Cicer arietinum $\mathrm{L}$.) to rhizobium inoculation and phosphorus fertilizer across smallholder farms in Ethiopia. Agric. , Ecosyst. Environ. 261, 144-152. https://doi.org/10.1016/j.agee.2018.01.035.

Yadav, B.K., 2011. Interaction Effect of Phosphorus and Sulphur on Yield and Quality of Clusterbean in Typic Haplustept. World J. Agric. Sci. 7, 556-560.

Yifru, A., Mesfin, K., 2013. Assessment on the status of some micronutrients in vertisols of the central Highlands of Ethiopia. Int. Res. J. Agric. Sci. Soil Sci. 3, 169-173.

Yoch, D.C., 1979. Electron-Transport Systems Coupled to Nitrogenase. Treatise Dinitrogen Fixat 605-652.

Zafar, S., Nasri, M., Moghadam, H.R.T., Zahedi, H., 2014. Effect of zinc and sulphur foliar applications on physiological characteristics of sunflower (Helianthus annuus L.) under water deficit stress. Int. J. Biosci. 5, 87-96.

Zaidi, A., Khan, M.S., Amil, M., 2003. Interactive effect of rhizotrophic microorganisms on yield and nutrient uptake of chickpea (Cicer arietinum L.). Eur. J. Agron. 19, 15-21.

Zerihun, G., Girma, A., Sheleme, B., 2017. Rhizobium inoculation and sulphur fertilizer improved yield, nutrients uptake and protein quality of soybean (Glysine max L.) varieties on Nitisols of Assosa area, Western Ethiopia. African J. Plant Sci. 11, 123-132. https://doi.org/10.5897/AJPS2017.1519.

Zhao, Yanwen, Xiao, X., Bi, D., Hu, F., 2008. Effects of Sulfur Fertilization on Soybean Root and Leaf Traits, and Soil Microbial Activity. J. Plant Nutr. 31, 473-483. https://doi.org/10.1080/01904160801895001.

\section{Figures}




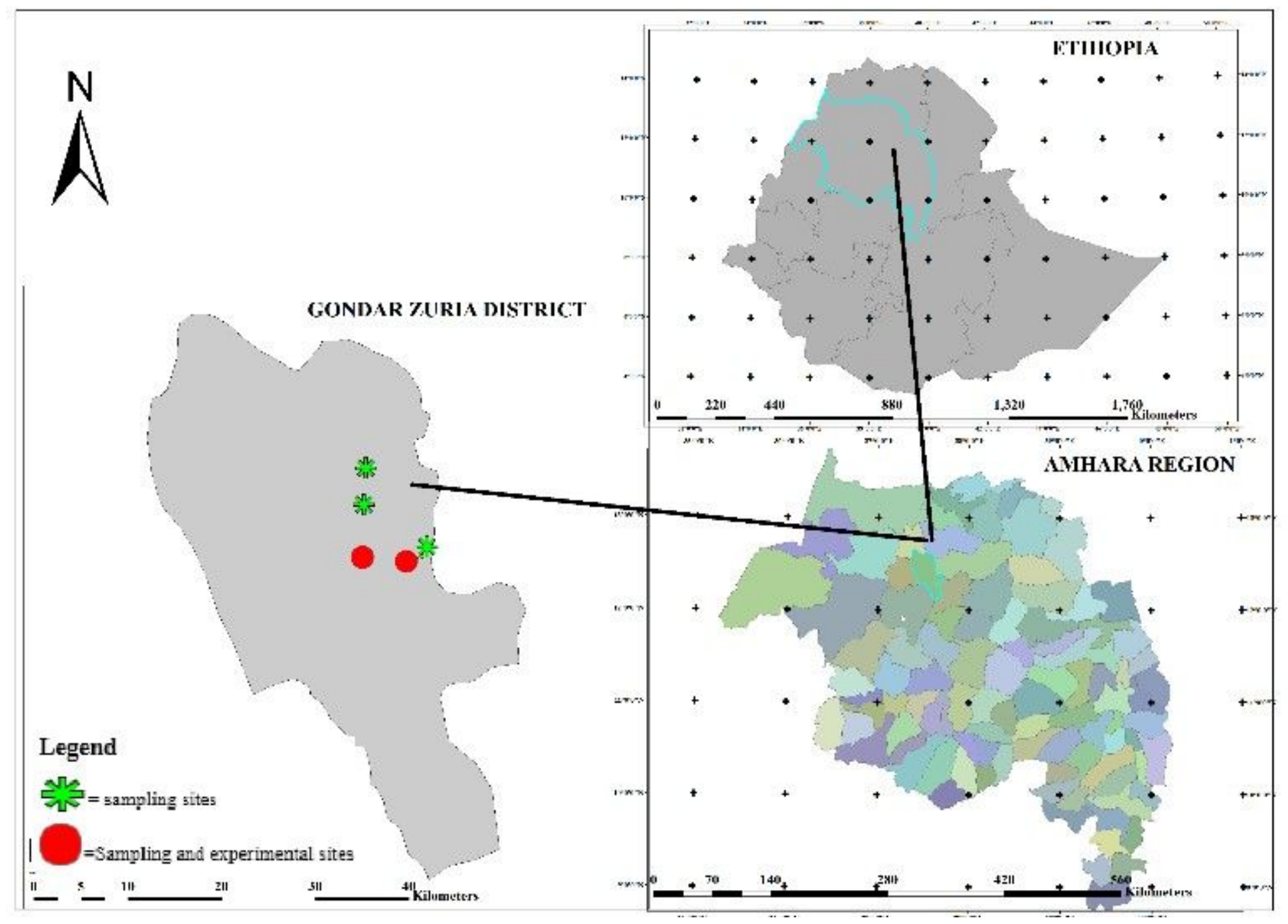

Figure 1

A map showing the location where soil sampling and the trial were conducted 


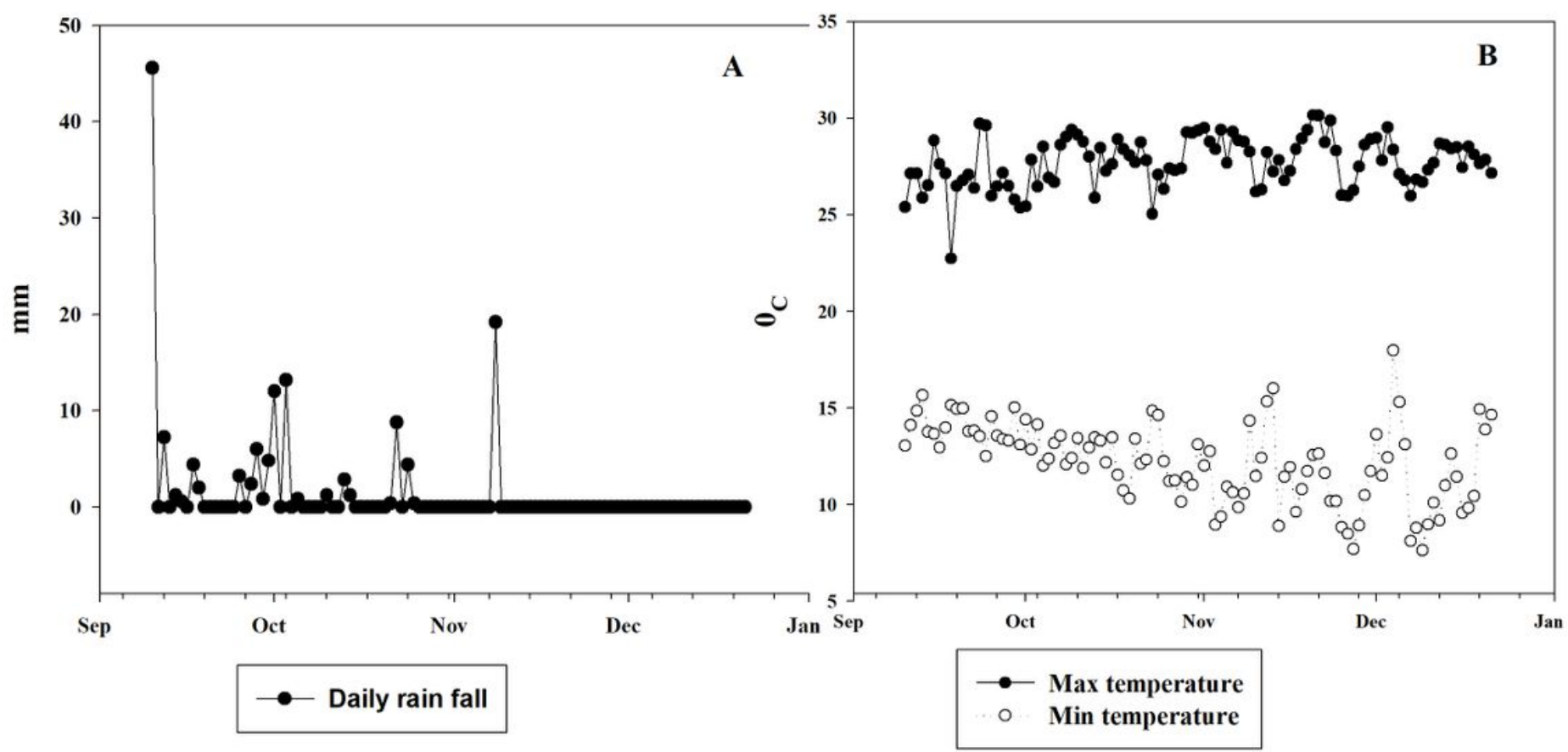

Figure 2

$A, B$, daily rain fall , maximum and minimum temperature during the growth period

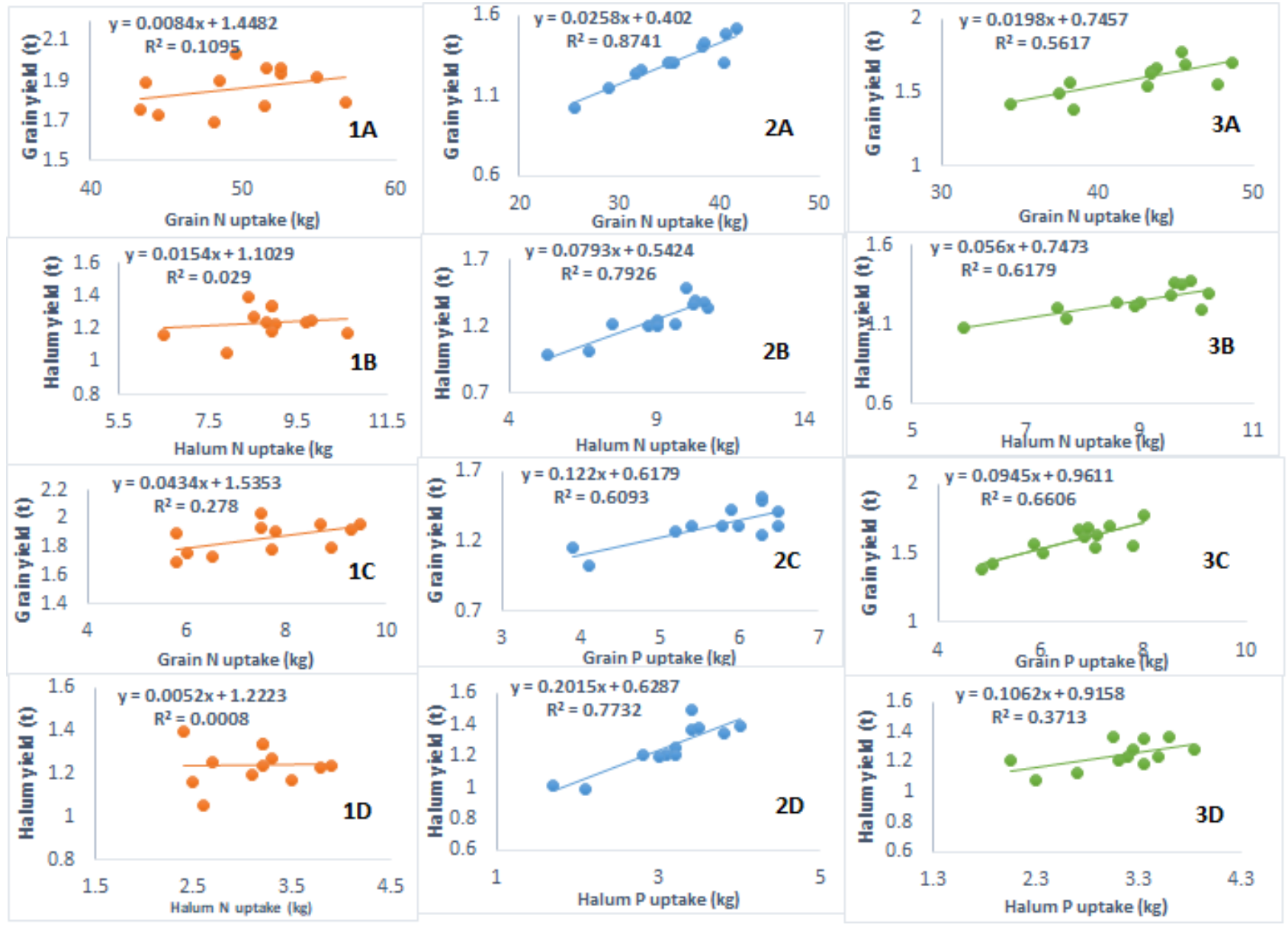


Figure 3

Correlation of biological yield with nutrient uptake $(1,2,3=$ Tsion, denzaz and mean respectively; $A, B, C, D=$ correlation of nutrient uptake with biological yield)

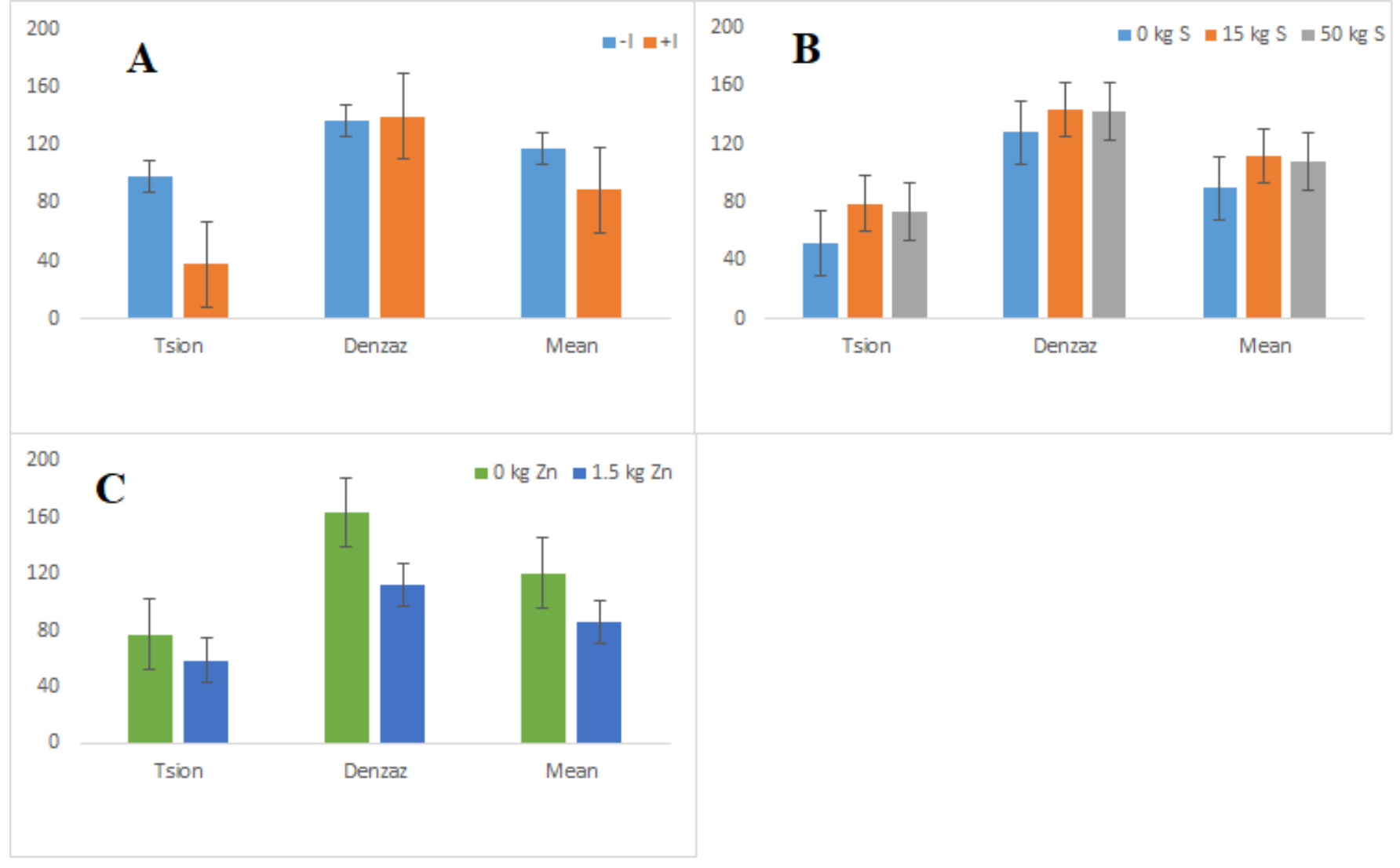

\section{Figure 4}

A, B and C- P use efficiency as influenced by level of Inoculation, $S$ and $Z n$ respectively 